\title{
Enhancing effect of dimethylamine in sulfuric acid nucleation in the presence of water - a computational study
}

\author{
V. Loukonen ${ }^{1}$, T. Kurtén ${ }^{1}$, I. K. Ortega ${ }^{1}$, H. Vehkamäki ${ }^{1}$, A. A. H. Pádua ${ }^{2}$, K. Sellegri ${ }^{3}$, and M. Kulmala ${ }^{1}$ \\ ${ }^{1}$ Division of Atmospheric Sciences, Department of Physics, P. O. Box 64, 00014 University of Helsinki, Finland \\ ${ }^{2}$ Laboratoire Thermodynamique et Interactions Moléculaires, Université Blaise Pascal, Clermont-Ferrand and CNRS, \\ 63177 Aubière, France \\ ${ }^{3}$ Laboratoire de Météorologie Physique, OPGC/CNRS, Université Blaise Pascal, 24 avenue des Landais, \\ 63170 Aubière, France
}

Received: 19 January 2010 - Published in Atmos. Chem. Phys. Discuss.: 1 February 2010

Revised: 3 May 2010 - Accepted: 21 May 2010 - Published: 28 May 2010

\begin{abstract}
We have studied the hydration of sulfuric acid - ammonia and sulfuric acid - dimethylamine clusters using quantum chemistry. We calculated the formation energies and thermodynamics for clusters of one ammonia or one dimethylamine molecule together with 1-2 sulfuric acid and $0-5$ water molecules. The results indicate that dimethylamine enhances the addition of sulfuric acid to the clusters much more efficiently than ammonia when the number of water molecules in the cluster is either zero, or greater than two. Further hydrate distribution calculations reveal that practically all dimethylamine-containing two-acid clusters will remain unhydrated in tropospherically relevant circumstances, thus strongly suggesting that dimethylamine assists atmospheric sulfuric acid nucleation much more effectively than ammonia.
\end{abstract}

\section{Introduction}

The fourth assessment report of the Intergovernmental Panel on Climate Change concludes that aerosols remain the dominant uncertainty in predicting radiative forcing and climate change (Intergovermental Panel for Climate Change, 2007; for a recent supplementary to the fourth IPCC report see e.g. The Copenhagen Diagnosis, 2009). Furthermore, modeling studies indicate that over the continents, around $30 \%$ of the total aerosol particle budget forms in the atmosphere

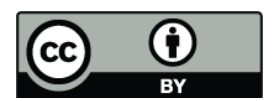

Correspondence to: V. Loukonen (ville.loukonen@helsinki.fi)
(Spracklen et al., 2006). However, despite its importance, the comprehension of the very first steps of aerosol particle formation, i.e. the microscopic understanding of nucleation, is still vague.

Currently, it is thought that the key ingredients in newparticle formation in the troposphere are sulfuric acid and water. Sulfuric acid concentrations have been observed to correlate with new-particle formation rates in a large variety of conditions (e.g., Weber et al., 1996, 1997; Kulmala et al., 2006; Sihto et al., 2006; Riipinen et al., 2007) and the ubiquitous water is most likely involved (Kulmala et al., 2004). It is also known, based on both experimental and theoretical results, that most of the observed new-particle formation events can not be explained by electrically neutral binary sulfuric acid-water nucleation alone. Therefore, atmospheric nucleation mechanisms have been proposed to involve contributions from ions, ammonia or various organic compounds (Korhonen et al., 1999; Kavouras et al., 1999; Kulmala et al., 2000; Yu and Turco, 2000).

Recently, the role of ions in atmospheric nucleation processes has been in the focus of intensive debate. There has been some controversy over the percentage contribution of ion-induced nucleation, with a few studies claiming that ion-induced nucleation dominates (e.g., Kazil et al., 2006; Yu and Turco, 2008) and others finding contributions of 110\% (e.g., Iida et al., 2006; Manninen et al., 2009). Recent observational studies (Kulmala et al., 2010) demonstrate a non-existent correlation between cosmic rays - the primary source of ions in the atmosphere - and nucleation rates or particle formation event frequencies, strongly suggesting that ion-induced nucleation pathways play only a minor role.

Published by Copernicus Publications on behalf of the European Geosciences Union. 
The role of ammonia in atmospheric nucleation has also been extensively discussed lately. At the moment, experiments and theoretical calculations are in qualitative agreement, stating that ammonia has a modest enhancing effect on sulfuric acid-water nucleation (Anttila et al., 2005; Kurtén et al., 2007b; Torpo et al., 2007; Nadykto et al., 2007; Ball et al., 2007). However, this effect is too small to explain the observed particle formation rates in the atmosphere. Clearly, there is a need for some other compounds to explain atmospheric observations. These compounds should also stabilize the sulfuric acid solution in the way that the saturation vapour pressure of sulfuric acid over the freshly formed particles is very small.

One such prominent possibility are the amines. Besides ammonia, amines are one of the few basic compounds present in the atmosphere, and as such can be expected to bind strongly to sulfuric acid.

Recent field (Mäkelä et al., 2001; Smith et al., 2008, 2010), laboratory (Murphy et al., 2007; Bzdek et al., 2010; Wang et al., 2010) and modelling (Barsanti et al., 2009) studies indicate that various amines might have a significant role in the formation and subsequent growth of new aerosol particles. Indeed, some amines may even be more effective than ammonia in enhancing the particle formation. In addition, in a recent quantum chemical study involving several amines possibly present in the vapor phase in the atmosphere, it was found that all of them formed significantly more strongly bound structures with sulfuric acid than ammonia (Kurtén et al., 2008). Although this was expected from e.g. proton affinity data, it was also demonstrated that dimethylamine assists the growth of both neutral and ionic clusters in the $\mathrm{H}_{2} \mathrm{SO}_{4}$ coordinate more effectively than ammonia, implying that amines are more likely to enhance sulfuric acid-water nucleation (Kurtén et al., 2008).

In this study we have explicitly investigated the hydration of dimethylamine - containing sulfuric acid clusters using quantum chemical methods, and compared their structures and properties to those of equally hydrated sulfuric acidammonia clusters. This study will give new insight especially on the role of dimethylamine in sulfuric acid driven nucleation in the presence of water, but it also adds new knowledge to the previous research on $\mathrm{H}_{2} \mathrm{SO}_{4}-\mathrm{H}_{2} \mathrm{O}$ (e.g., Bandy and Ianni, 1998; Re et al., 1999; Ding et al., 2003; Al Natsheh et al., 2004; Kurtén et al., 2007a) and $\mathrm{H}_{2} \mathrm{SO}_{4}-\mathrm{NH}_{3}-\mathrm{H}_{2} \mathrm{O}$ (e.g., Ianni and Bandy, 1999; Larson et al., 1999; Kurtén et al., 2007b;) clusters. Focusing particularly on dimethylamine is a choice guided partly by previous results. For instance, in one study dimethlyammonium $\left(\left(\mathrm{CH}_{3}\right)_{2} \mathrm{NH}_{2}^{+}\right)$concentrations in accumulation mode aerosol particles during nucleation event days in boreal forest conditions was measured to be 50 times higher than during non-event days, thus strongly indicating that dimethylamine was involved in particle formation (Mäkelä et al., 2001). Furthermore, as a disubstituted amine dimethylamine may be regarded as a sort of "average amine" with respect to the basicity and the number of hydro- gen bonds it can form. The choice was also partly guided by practical limitations: inclusion of e.g. all the other alkylamines in this study would be computationally unfeasible.

\section{Computational details}

The calculations were carried out applying a systematic multi-step procedure for quantum chemistry (Ortega et al., 2008) with additional molecular dynamics (MD) simulations. Part of the initial structures were taken from previous studies when available, and created using chemical intuition when not. However, as the size of the cluster grows, the number of possible bonding patterns increases rapidly, and so the task of finding the most stable conformer for a large cluster becomes nontrivial. To overcome this inevitable problem of all quantum chemistry cluster studies, we used MD simulations to generate additional initial guesses for all the structures, thus covering the configuration-space more thoroughly. This was done with the DL_POLY_2 program (Smith et al., 2002) and custom-built force fields. We used a simple three-step simulated annealing optimization method, with the temperatures $1500 \mathrm{~K}, 200 \mathrm{~K}$ and $0.1 \mathrm{~K}$, taking the relaxed structures after the last step as a guess structure for the conformer in question. The force-fields used were non-reactive, so e.g. proton transfer reactions could not be modeled dynamically and therefore the different stages of deprotonation had to be taken into account manually by performing simulations of different protonation states for the structures. Force-field parameters and additional MD simulation details are given in the supplementary material, see http://www.atmos-chem-phys.net/10/ 4961/2010/acp-10-4961-2010-supplement.zip.

Once a fair set of initial guesses (min. 10) for every structure was collected, we optimized the clusters with the SIESTA program (Soler et al., 2002), using the BLYP (Mielhich et al., 1989) functional and the DZP basis set with tight convergence criteria $(0.01 \mathrm{eV} / \mathrm{Ang}$ force tolerance with a step size of 0.02 Bohr for geometry optimization and a step size of 0.01 Bohr for frequencies). The BLYP/DZPcombination for the geometry optimization is based on performance studies for molecular clusters optimization using the SIESTA program. This particular choice was found to be the best between accuracy and computational effort (Ortega et al., 2008). For each stoichiometry, several of the most promising (lowest-energy) clusters were then chosen for single-point energy calculations with the TURBOMOLE program (Ahlrichs et al., 1989), using the RI-MP2 (Bernholdt et al., 1996; Møller and Plesset, 1934) method with the aug-cc-pV(T+d)Z (Dunning et al., 2001) basis set. Although DFT-methods in general have problems describing weak interactions arising from dispersion forces, the geometries and vibrational frequencies should be qualitatively reliable. The dispersion contribution to the final electronic energies is then taken into account more faithfully by the 
RI-MP2 calculations. Previously performed basis set extrapolation calculations (Kurtén et al., 2007a, b) showed that for the RI-MP2 method the basis set effects beyond the aug-cc$\mathrm{pV}(\mathrm{T}+\mathrm{d}) \mathrm{Z}$ level are relatively small, so the chosen basis set should be accurate enough for our present purposes. Furthermore, as we are primarily interested in relative binding energies, inaccuraries such as basis set superposition error have an even smaller effect on our energetics.

Thermal contributions to the Gibbs free energies were estimated using the standard harmonic oscillator and rigid rotor approximations, with reference conditions of $298.15 \mathrm{~K}$ and $1 \mathrm{~atm}$. However, in nature the molecular clusters are far from rigid or harmonic. We took these physical anharmonicities into account by scaling the calculated vibrational frequencies, since the explicit calculation of anharmonic vibrational frequencies for even a medium size cluster is practically impossible due to the extremely high computational cost.

For some of the smaller clusters under study (free water, free sulfuric acid, mono- and dihydrates of sulfuric acid) the scaling factors were obtained by comparison with high-level (MP2/aug-cc-pV(D+d)Z level) anharmonic literature values (Kurtén et al., 2007a). To obtain scaling factors for free ammonia and dimethylamine, the corresponding anharmonic frequencies were explicitly calculated using the GAUSSIAN 03 program suite (Gaussian 03, Revision C.02, 2004) at the MP2/aug-cc-pVDZ level of theory.

For all the individual vibrational frequencies $(3 \mathrm{~N}-6$ for molecules/clusters with $\mathrm{N}$ atoms) of the abovementioned free molecules and small clusters, we computed the ratios of the high-level anharmonic values to the harmonic frequencies calculated with SIESTA. This yielded an estimate for the deviation from the real (anharmonic) vibrations caused by the harmonic approximation. The scaling factor corresponding to the structure in question was then constructed by taking an average of the ratios. Of course, this procedure does not differentiate between the differences originating from the harmonic approximation and those inherent to the methods and basis sets used for the electronic structure calculation. It is an inescapable fact that some fraction of the real physical anharmonicity is always beyond the reach of even the best imaginable computational approach. Since the purpose of this study is not to investigate the nature of the vibrational anharmonicity per se, but to use applied quantum mechanics to assess the nucleation enhancing roles of dimethylamine and ammonia, the use of the scaling procedure described is well justified, as it provides predictive, qualitative accuracy.

In this study we did not take into account the fact that the enthaply and entropy are relatively more sensitive to the lowfrequency vibrations, but used the abovementioned scaling factors as such for the entropies and for the thermal parts of enthalpies. However, for the zero-point vibrational energy contribution of the enthalpies, the scaling factor $s$ was modified to $s_{\mathrm{ZPE}}$ :

$s_{\mathrm{ZPE}}=0.5(1+s)$.
Table 1. The individual scaling factors used in this study; $s$ for the entropies and thermal parts of enthalpies, and $s_{Z P E}$ for the zeropoint vibrational energy contribution of enthalpy. Here "monohydrate" refers to the monohydrate of sulfuric acid and "dihydrate" to the dihydrate of sulfuric acid. The lower part of the table shows a comparison between the averages of the individual scaling factors used in this study and other scaling factors for some common exchange and correlation functionals (Merrick et al., 2007). However, the values are not directly comparable as they are obtained using different procedures.

\begin{tabular}{lrr}
\hline complex & scaling factor & scaling factor \\
& $s$ & $s$ ZPE \\
\hline water & 0.99079 & 0.99540 \\
ammonia & 0.98543 & 0.99271 \\
dimethylamine & 1.00964 & 1.00482 \\
sulfuric acid & 0.99732 & 0.99866 \\
monohydrate & 0.90305 & 0.95152 \\
dihydrate & 0.84271 & 0.92136 \\
average & 0.95482 & 0.97741 \\
\hline method & scaling factor & scaling factor \\
& $s$ & $s \mathrm{ZPE}$ \\
\hline this study & 0.9548 & 0.9774 \\
B-LYP/6-31G(d) & 0.9940 & 1.0135 \\
B-LYP/6-311+G(2df,p) & 0.9994 & 1.0186 \\
B1-LYP/6-31G(d) & 0.9561 & 0.9760 \\
B1-LYP/6-311+G(2df,p) & 0.9639 & 0.9840 \\
B3-LYP/6-31G(d) & 0.9613 & 0.9813 \\
B3-LYP/6-311+G(2df,p) & 0.9686 & 0.9889 \\
O3-LYP/6-31G(d) & 0.9617 & 0.9826 \\
O3-LYP/6-311+G(2df,p) & 0.9701 & 0.9918 \\
\hline
\end{tabular}

This approach seems to capture the qualitative behavior of the scaling factors generally used for thermal contributions and zero-point vibrational energies (see for example Grev et al. (1991), Scott and Radom (1996) and Merrick et al. (2007) for more discussion on the scaling factors).

The individual scaling factors used in this study are collected in Table 1. Table 1 shows also the averages of the individual scaling factors used in this study in comparison with other scaling factors (taken from Merrick et al., 2007) for the same exchange or correlation functionals as used here. It should be noted that the scaling factors used in this study and the literature scaling factors are not directly comparable, as they are obtained by different procedures. However, it can be seen that most often the scaling factors used for zero-point energy contribution are closer to unity than the ones used for other contributions.

By this, we obtained the scaling factors needed for the calculations of thermal contributions to the formation energies for free water, sulfuric acid, ammonia, dimethylamine, mono- and dihydrates of sulfuric acid. For the other dimer structures $\left(\left(\mathrm{H}_{2} \mathrm{SO}_{4}\right)_{2}, \mathrm{H}_{2} \mathrm{SO}_{4} \cdot \mathrm{NH}_{3}, \mathrm{H}_{2} \mathrm{SO}_{4} \cdot\left(\mathrm{CH}_{3}\right)_{2} \mathrm{NH}\right)$ we 


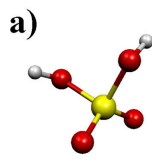

d)

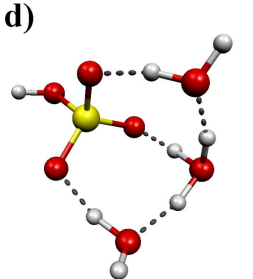

b)

e)

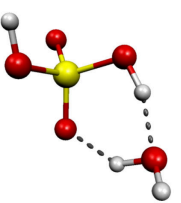

c)

f)

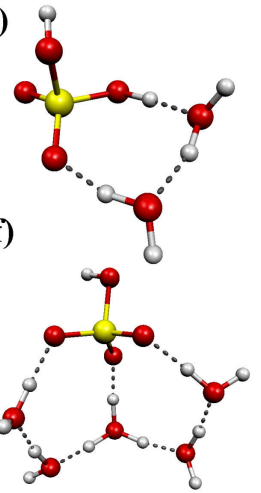

Fig. 1. The most stable structures with respect to the formation free energy $\Delta G$ (at $T=298.15 \mathrm{~K}$ and $P=1 \mathrm{~atm}$ ) for clusters consisting of one sulfuric acid and 0-5 water molecules: (a) $\mathrm{H}_{2} \mathrm{SO}_{4}$, (b) $\mathrm{H}_{2} \mathrm{SO}_{4} \cdot \mathrm{H}_{2} \mathrm{O}$, (c) $\mathrm{H}_{2} \mathrm{SO}_{4} \cdot\left(\mathrm{H}_{2} \mathrm{O}\right)_{2}$, (d) $\mathrm{H}_{2} \mathrm{SO}_{4} \cdot\left(\mathrm{H}_{2} \mathrm{O}\right)_{3}$, (e) $\mathrm{H}_{2} \mathrm{SO}_{4} \cdot\left(\mathrm{H}_{2} \mathrm{O}\right)_{4}$, (f) $\mathrm{H}_{2} \mathrm{SO}_{4} \cdot\left(\mathrm{H}_{2} \mathrm{O}\right)_{5}$.

used the scaling factors of the monohydrate. For other structures with more than two molecules, we used the scaling factors of the dihydrate. This will introduce some extra inaccuracy to the scheme, but as it is probable that the relative differences in scaling factors get smaller as the size of the clusters grows, the effect for qualitative accuracy is considered to be negligible. In general, the uncertainty in the absolute formation free energies obtained as described above can be several kilocalories per mole. However, in this study we are mainly interested in the the relative formation free energies, and the uncertainty related to those values is most likely on the order of 1-2 kcal/mol (see e.g. Kurtén and Vehkamäki, 2008).

The harmonic and anharmonic frequencies, and the derivation of the scaling factors are given as a supplementary material, see http://www.atmos-chem-phys.net/10/4961/2010/ acp-10-4961-2010-supplement.zip.

\section{Results and discussion}

The electronic energies $\Delta E_{\text {elec }}$ (at the RI-MP2/aug-cc$\mathrm{pV}(\mathrm{T}+\mathrm{d}) \mathrm{Z}$ level of theory) and the corresponding thermodynamical quantities enthalpy $\Delta H$, entropy $\Delta S$ and the Gibbs free energy $\Delta G$ (at $T=298.15 \mathrm{~K}$ and $P=1 \mathrm{~atm}$ ) for the formation of all the complexes under study from individual constituent molecules are presented in Table 2. The most stable clusters with respect to the Gibbs free energy $\Delta G$ at $T=298.15 \mathrm{~K}$ and $P=1 \mathrm{~atm}$ are shown in Figs. 1-6. In all the Figs. 1-6, the a)-structures are the non-hydrated ones, the b)structures the monohydrates, the c)-structures the dihydrates, and so on. The sulfur atoms are depicted in yellow, oxygen atoms in red, nitrogen atoms in blue, carbon atoms in green and the hydrogen atoms in white. The hydrogen bonds are indicated with dotted lines. a)

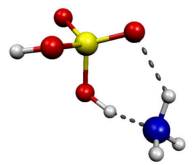

d)
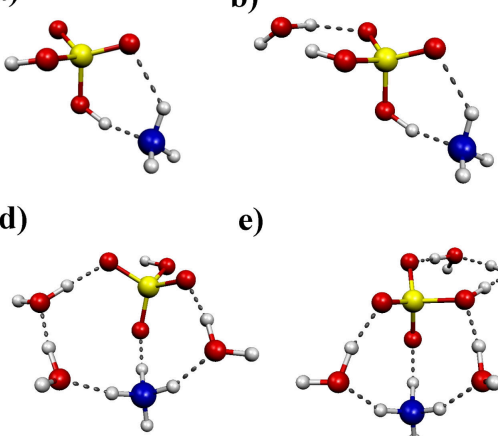

e)

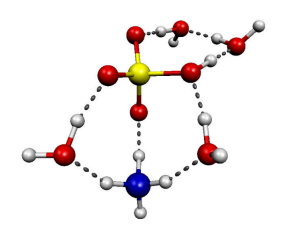

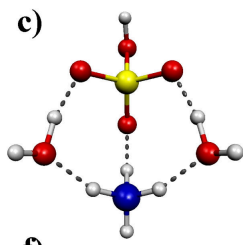

f)

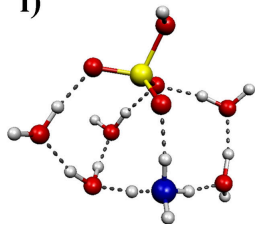

Fig. 2. The most stable structures with respect to the formation free energy $\Delta G$ (at $T=298.15 \mathrm{~K}$ and $P=1 \mathrm{~atm}$ ) for clusters consisting of one sulfuric acid with ammonia and 0 5 water molecules: (a) $\mathrm{H}_{2} \mathrm{SO}_{4} \cdot \mathrm{NH}_{3}$, (b) $\mathrm{H}_{2} \mathrm{SO}_{4} \cdot \mathrm{NH}_{3} \cdot \mathrm{H}_{2} \mathrm{O}$, (c) $\mathrm{H}_{2} \mathrm{SO}_{4} \cdot \mathrm{NH}_{3} \cdot\left(\mathrm{H}_{2} \mathrm{O}\right)_{2}, \quad$ (d) $\mathrm{H}_{2} \mathrm{SO}_{4} \cdot \mathrm{NH}_{3} \cdot\left(\mathrm{H}_{2} \mathrm{O}\right)_{3}, \quad$ (e) $\mathrm{H}_{2} \mathrm{SO}_{4} \cdot \mathrm{NH}_{3} \cdot\left(\mathrm{H}_{2} \mathrm{O}\right)_{4},\left(\right.$ f) $\mathrm{H}_{2} \mathrm{SO}_{4} \cdot \mathrm{NH}_{3} \cdot\left(\mathrm{H}_{2} \mathrm{O}\right)_{5}$.

a)

d)
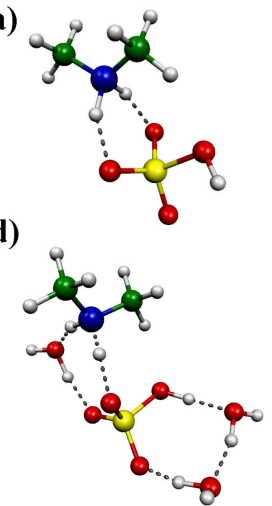

b)

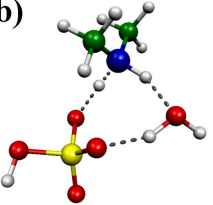

e)

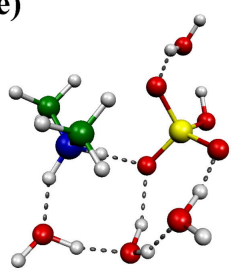

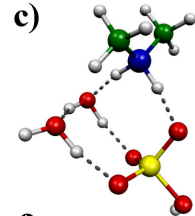

f)

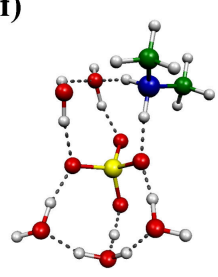

Fig. 3. The most stable structures with respect to the formation free energy $\Delta G$ (at $T=298.15 \mathrm{~K}$ and $P=1 \mathrm{~atm}$ ) for clusters consisting of one sulfuric acid with dimethylamine and $0-5$ water molecules: (a) $\mathrm{H}_{2} \mathrm{SO}_{4} \cdot\left(\mathrm{CH}_{3}\right)_{2} \mathrm{NH}$, (b) $\mathrm{H}_{2} \mathrm{SO}_{4} \cdot\left(\mathrm{CH}_{3}\right)_{2} \mathrm{NH} \cdot \mathrm{H}_{2} \mathrm{O}$, (c) $\mathrm{H}_{2} \mathrm{SO}_{4} \cdot\left(\mathrm{CH}_{3}\right)_{2} \mathrm{NH} \cdot\left(\mathrm{H}_{2} \mathrm{O}\right)_{2}$, (d) $\mathrm{H}_{2} \mathrm{SO}_{4} \cdot\left(\mathrm{CH}_{3}\right)_{2} \mathrm{NH} \cdot\left(\mathrm{H}_{2} \mathrm{O}\right)_{3}$, (e) $\mathrm{H}_{2} \mathrm{SO}_{4} \cdot\left(\mathrm{CH}_{3}\right)_{2} \mathrm{NH} \cdot\left(\mathrm{H}_{2} \mathrm{O}\right)_{4}$, (f) $\mathrm{H}_{2} \mathrm{SO}_{4} \cdot\left(\mathrm{CH}_{3}\right)_{2} \mathrm{NH} \cdot\left(\mathrm{H}_{2} \mathrm{O}\right)_{5}$.

\subsection{Acid addition}

In order to compare the enhancing (nucleation barrierlowering) effects of dimethylamine and ammonia in sulfuric acid-water nucleation, we have calculated the Gibbs free energies of the addition of one $\mathrm{H}_{2} \mathrm{SO}_{4}$ molecule to clusters consisting of one sulfuric acid, ammonia or dimethylamine and $0-5$ water molecules. These values are also compared to the corresponding free energies for clusters with only sulfuric acid and water. The results, obtained from the values given in Table 2 as ( $\Delta G$ of acid addition) $=\Delta G\left(n_{\text {acids }}\right)-\Delta G\left(n_{\text {acids }}-1\right)$, where $\Delta G\left(n_{\text {acids }}\right)$ is the formation free energy for a complex with $n_{\text {acids }}$ sulfuric acid molecules, are shown in Fig. 7. 
Table 2. The electronic binding energies $\Delta E_{\text {elec }}$ (at the RI-MP2/aug-cc-pV(T+d)Z level of theory) and the thermochemical parameters enthalpy $\Delta H$, entropy $\Delta S$ and the Gibbs free energy $\Delta G$ (at $T=298.15 \mathrm{~K}$ and $P=1 \mathrm{~atm}$ ) for the formation of molecular clusters under study.

\begin{tabular}{|c|c|c|c|c|}
\hline Reaction & $\begin{array}{r}\Delta E_{\text {elec }} \\
(\mathrm{kcal} / \mathrm{mol})\end{array}$ & $\begin{array}{r}\Delta H \\
(\mathrm{kcal} / \mathrm{mol})\end{array}$ & $\begin{array}{r}\Delta S \\
(\mathrm{cal} /(\operatorname{mol~K}))\end{array}$ & $\begin{array}{r}\Delta G \\
(\mathrm{kcal} / \mathrm{mol})\end{array}$ \\
\hline $\begin{array}{l}\mathrm{H}_{2} \mathrm{SO}_{4}+\mathrm{H}_{2} \mathrm{O} \rightarrow \mathrm{H}_{2} \mathrm{SO}_{4} \cdot \mathrm{H}_{2} \mathrm{O} \\
\mathrm{H}_{2} \mathrm{SO}_{4}+2 \mathrm{H}_{2} \mathrm{O} \rightarrow \mathrm{H}_{2} \mathrm{SO}_{4} \cdot\left(\mathrm{H}_{2} \mathrm{O}\right)_{2} \\
\mathrm{H}_{2} \mathrm{SO}_{4}+3 \mathrm{H}_{2} \mathrm{O} \rightarrow \mathrm{H}_{2} \mathrm{SO}_{4} \cdot\left(\mathrm{H}_{2} \mathrm{O}\right)_{3} \\
\mathrm{H}_{2} \mathrm{SO}_{4}+4 \mathrm{H}_{2} \mathrm{O} \rightarrow \mathrm{H}_{2} \mathrm{SO}_{4} \cdot\left(\mathrm{H}_{2} \mathrm{O}\right)_{4} \\
\mathrm{H}_{2} \mathrm{SO}_{4}+5 \mathrm{H}_{2} \mathrm{O} \rightarrow \mathrm{H}_{2} \mathrm{SO}_{4} \cdot\left(\mathrm{H}_{2} \mathrm{O}\right)_{5}\end{array}$ & $\begin{array}{l}-12.04 \\
-24.20 \\
-35.89 \\
-49.79 \\
-58.59\end{array}$ & $\begin{array}{l}-11.98 \\
-24.97 \\
-36.66 \\
-49.30 \\
-57.70\end{array}$ & $\begin{array}{r}-30.37 \\
-62.74 \\
-99.12 \\
-138.14 \\
-159.92\end{array}$ & $\begin{array}{r}-2.93 \\
-6.26 \\
-7.11 \\
-8.11 \\
-10.01\end{array}$ \\
\hline $\begin{array}{l}\mathrm{H}_{2} \mathrm{SO}_{4}+\mathrm{NH}_{3} \rightarrow \mathrm{H}_{2} \mathrm{SO}_{4} \cdot \mathrm{NH}_{3} \\
\mathrm{H}_{2} \mathrm{SO}_{4}+\mathrm{NH}_{3}+\mathrm{H}_{2} \mathrm{O} \rightarrow \mathrm{H}_{2} \mathrm{SO}_{4} \cdot \mathrm{NH}_{3} \cdot \mathrm{H}_{2} \mathrm{O} \\
\mathrm{H}_{2} \mathrm{SO}_{4}+\mathrm{NH}_{3}+2 \mathrm{H}_{2} \mathrm{O} \rightarrow \mathrm{H}_{2} \mathrm{SO}_{4} \cdot \mathrm{NH}_{3} \cdot\left(\mathrm{H}_{2} \mathrm{O}\right)_{2} \\
\mathrm{H}_{2} \mathrm{SO}_{4}+\mathrm{NH}_{3}+3 \mathrm{H}_{2} \mathrm{O} \rightarrow \mathrm{H}_{2} \mathrm{SO}_{4} \cdot \mathrm{NH}_{3} \cdot\left(\mathrm{H}_{2} \mathrm{O}\right)_{3} \\
\mathrm{H}_{2} \mathrm{SO}_{4}+\mathrm{NH}_{3}+4 \mathrm{H}_{2} \mathrm{O} \rightarrow \mathrm{H}_{2} \mathrm{SO}_{4} \cdot \mathrm{NH}_{3} \cdot\left(\mathrm{H}_{2} \mathrm{O}\right)_{4} \\
\mathrm{H}_{2} \mathrm{SO}_{4}+\mathrm{NH}_{3}+5 \mathrm{H}_{2} \mathrm{O} \rightarrow \mathrm{H}_{2} \mathrm{SO}_{4} \cdot \mathrm{NH}_{3} \cdot\left(\mathrm{H}_{2} \mathrm{O}\right)_{5}\end{array}$ & $\begin{array}{l}-16.57 \\
-28.05 \\
-44.30 \\
-55.30 \\
-66.30 \\
-78.74\end{array}$ & $\begin{array}{l}-17.87 \\
-29.22 \\
-43.78 \\
-54.41 \\
-64.95 \\
-76.05\end{array}$ & $\begin{array}{r}-29.06 \\
-63.57 \\
-99.94 \\
-128.30 \\
-163.93 \\
-193.03\end{array}$ & $\begin{array}{r}-9.21 \\
-10.26 \\
-13.98 \\
-16.16 \\
-16.07 \\
-18.49\end{array}$ \\
\hline $\begin{array}{l}\mathrm{H}_{2} \mathrm{SO}_{4}+\left(\mathrm{CH}_{3}\right)_{2} \mathrm{NH} \rightarrow \mathrm{H}_{2} \mathrm{SO}_{4} \cdot\left(\mathrm{CH}_{3}\right)_{2} \mathrm{NH} \\
\mathrm{H}_{2} \mathrm{SO}_{4}+\left(\mathrm{CH}_{3}\right)_{2} \mathrm{NH}+\mathrm{H}_{2} \mathrm{O} \rightarrow \mathrm{H}_{2} \mathrm{SO}_{4} \cdot\left(\mathrm{CH}_{3}\right)_{2} \mathrm{NH} \cdot \mathrm{H}_{2} \mathrm{O} \\
\mathrm{H}_{2} \mathrm{SO}_{4}+\left(\mathrm{CH}_{3}\right)_{2} \mathrm{NH}+2 \mathrm{H}_{2} \mathrm{O} \rightarrow \mathrm{H}_{2} \mathrm{SO}_{4} \cdot\left(\mathrm{CH}_{3}\right)_{2} \mathrm{NH} \cdot\left(\mathrm{H}_{2} \mathrm{O}\right)_{2} \\
\mathrm{H}_{2} \mathrm{SO}_{4}+\left(\mathrm{CH}_{3}\right)_{2} \mathrm{NH}+3 \mathrm{H}_{2} \mathrm{O} \rightarrow \mathrm{H}_{2} \mathrm{SO}_{4} \cdot\left(\mathrm{CH}_{3}\right)_{2} \mathrm{NH} \cdot\left(\mathrm{H}_{2} \mathrm{O}\right)_{3} \\
\mathrm{H}_{2} \mathrm{SO}_{4}+\left(\mathrm{CH}_{3}\right)_{2} \mathrm{NH}+4 \mathrm{H}_{2} \mathrm{O} \rightarrow \mathrm{H}_{2} \mathrm{SO}_{4} \cdot\left(\mathrm{CH}_{3}\right)_{2} \mathrm{NH} \cdot\left(\mathrm{H}_{2} \mathrm{O}\right)_{4} \\
\mathrm{H}_{2} \mathrm{SO}_{4}+\left(\mathrm{CH}_{3}\right)_{2} \mathrm{NH}+5 \mathrm{H}_{2} \mathrm{O} \rightarrow \mathrm{H}_{2} \mathrm{SO}_{4} \cdot\left(\mathrm{CH}_{3}\right)_{2} \mathrm{NH} \cdot\left(\mathrm{H}_{2} \mathrm{O}\right)_{5}\end{array}$ & $\begin{array}{l}-24.42 \\
-40.07 \\
-52.19 \\
-62.30 \\
-75.48 \\
-84.49\end{array}$ & $\begin{array}{l}-26.41 \\
-43.11 \\
-54.01 \\
-63.74 \\
-75.03 \\
-84.72\end{array}$ & $\begin{array}{r}-36.36 \\
-67.16 \\
-103.84 \\
-135.73 \\
-172.53 \\
-208.54\end{array}$ & $\begin{array}{l}-15.57 \\
-23.09 \\
-23.05 \\
-23.28 \\
-23.59 \\
-22.55\end{array}$ \\
\hline $\begin{array}{l}2 \mathrm{H}_{2} \mathrm{SO}_{4} \rightarrow\left(\mathrm{H}_{2} \mathrm{SO}_{4}\right)_{2} \\
2 \mathrm{H}_{2} \mathrm{SO}_{4}+\mathrm{H}_{2} \mathrm{O} \rightarrow\left(\mathrm{H}_{2} \mathrm{SO}_{4}\right)_{2} \cdot \mathrm{H}_{2} \mathrm{O} \\
2 \mathrm{H}_{2} \mathrm{SO}_{4}+2 \mathrm{H}_{2} \mathrm{O} \rightarrow\left(\mathrm{H}_{2} \mathrm{SO}_{4}\right)_{2} \cdot\left(\mathrm{H}_{2} \mathrm{O}\right)_{2} \\
2 \mathrm{H}_{2} \mathrm{SO}_{4}+3 \mathrm{H}_{2} \mathrm{O} \rightarrow\left(\mathrm{H}_{2} \mathrm{SO}_{4}\right)_{2} \cdot\left(\mathrm{H}_{2} \mathrm{O}\right)_{3} \\
2 \mathrm{H}_{2} \mathrm{SO}_{4}+4 \mathrm{H}_{2} \mathrm{O} \rightarrow\left(\mathrm{H}_{2} \mathrm{SO}_{4}\right)_{2} \cdot\left(\mathrm{H}_{2} \mathrm{O}\right)_{4} \\
2 \mathrm{H}_{2} \mathrm{SO}_{4}+5 \mathrm{H}_{2} \mathrm{O} \rightarrow\left(\mathrm{H}_{2} \mathrm{SO}_{4}\right)_{2} \cdot\left(\mathrm{H}_{2} \mathrm{O}\right)_{5}\end{array}$ & $\begin{array}{l}-18.92 \\
-32.86 \\
-48.35 \\
-59.94 \\
-72.56 \\
-88.35\end{array}$ & $\begin{array}{l}-20.53 \\
-35.01 \\
-49.65 \\
-60.31 \\
-72.12 \\
-86.81\end{array}$ & $\begin{array}{r}-32.69 \\
-68.50 \\
-106.34 \\
-138.18 \\
-173.66 \\
-216.29\end{array}$ & $\begin{array}{l}-10.78 \\
-14.59 \\
-17.95 \\
-19.11 \\
-20.34 \\
-22.32\end{array}$ \\
\hline $\begin{array}{l}2 \mathrm{H}_{2} \mathrm{SO}_{4}+\mathrm{NH}_{3} \rightarrow\left(\mathrm{H}_{2} \mathrm{SO}_{4}\right)_{2} \cdot \mathrm{NH}_{3} \\
2 \mathrm{H}_{2} \mathrm{SO}_{4}+\mathrm{NH}_{3}+\mathrm{H}_{2} \mathrm{O} \rightarrow\left(\mathrm{H}_{2} \mathrm{SO}_{4}\right)_{2} \cdot \mathrm{NH}_{3} \cdot \mathrm{H}_{2} \mathrm{O} \\
2 \mathrm{H}_{2} \mathrm{SO}_{4}+\mathrm{NH}_{3}+2 \mathrm{H}_{2} \mathrm{O} \rightarrow\left(\mathrm{H}_{2} \mathrm{SO}_{4}\right)_{2} \cdot \mathrm{NH}_{3} \cdot\left(\mathrm{H}_{2} \mathrm{O}\right)_{2} \\
2 \mathrm{H}_{2} \mathrm{SO}_{4}+\mathrm{NH}_{3}+3 \mathrm{H}_{2} \mathrm{O} \rightarrow\left(\mathrm{H}_{2} \mathrm{SO}_{4}\right)_{2} \cdot \mathrm{NH}_{3} \cdot\left(\mathrm{H}_{2} \mathrm{O}\right)_{3} \\
2 \mathrm{H}_{2} \mathrm{SO}_{4}+\mathrm{NH}_{3}+4 \mathrm{H}_{2} \mathrm{O} \rightarrow\left(\mathrm{H}_{2} \mathrm{SO}_{4}\right)_{2} \cdot \mathrm{NH}_{3} \cdot\left(\mathrm{H}_{2} \mathrm{O}\right)_{4} \\
2 \mathrm{H}_{2} \mathrm{SO}_{4}+\mathrm{NH}_{3}+5 \mathrm{H}_{2} \mathrm{O} \rightarrow\left(\mathrm{H}_{2} \mathrm{SO}_{4}\right)_{2} \cdot \mathrm{NH}_{3} \cdot\left(\mathrm{H}_{2} \mathrm{O}\right)_{5}\end{array}$ & $\begin{array}{r}-46.20 \\
-59.81 \\
-68.54 \\
-86.95 \\
-95.83 \\
-109.44\end{array}$ & $\begin{array}{r}-47.54 \\
-60.26 \\
-68.24 \\
-85.86 \\
-93.66 \\
-107.26\end{array}$ & $\begin{array}{r}-75.16 \\
-105.94 \\
-139.90 \\
-183.01 \\
-215.91 \\
-250.69\end{array}$ & $\begin{array}{l}-25.13 \\
-28.68 \\
-26.53 \\
-31.29 \\
-29.28 \\
-32.51\end{array}$ \\
\hline $\begin{array}{l}2 \mathrm{H}_{2} \mathrm{SO}_{4}+\left(\mathrm{CH}_{3}\right)_{2} \mathrm{NH} \rightarrow\left(\mathrm{H}_{2} \mathrm{SO}_{4}\right)_{2} \cdot\left(\mathrm{CH}_{3}\right)_{2} \mathrm{NH} \\
2 \mathrm{H}_{2} \mathrm{SO}_{4}+\left(\mathrm{CH}_{3}\right)_{2} \mathrm{NH}+\mathrm{H}_{2} \mathrm{O} \rightarrow\left(\mathrm{H}_{2} \mathrm{SO}_{4}\right)_{2} \cdot\left(\mathrm{CH}_{3}\right)_{2} \mathrm{NH} \cdot \mathrm{H}_{2} \mathrm{O} \\
2 \mathrm{H}_{2} \mathrm{SO}_{4}+\left(\mathrm{CH}_{3}\right)_{2} \mathrm{NH}+2 \mathrm{H}_{2} \mathrm{O} \rightarrow\left(\mathrm{H}_{2} \mathrm{SO}_{4}\right)_{2} \cdot\left(\mathrm{CH}_{3}\right)_{2} \mathrm{NH} \cdot\left(\mathrm{H}_{2} \mathrm{O}\right)_{2} \\
2 \mathrm{H}_{2} \mathrm{SO}_{4}+\left(\mathrm{CH}_{3}\right)_{2} \mathrm{NH}+3 \mathrm{H}_{2} \mathrm{O} \rightarrow\left(\mathrm{H}_{2} \mathrm{SO}_{4}\right)_{2} \cdot\left(\mathrm{CH}_{3}\right)_{2} \mathrm{NH} \cdot\left(\mathrm{H}_{2} \mathrm{O}\right)_{3} \\
2 \mathrm{H}_{2} \mathrm{SO}_{4}+\left(\mathrm{CH}_{3}\right)_{2} \mathrm{NH}+4 \mathrm{H}_{2} \mathrm{O} \rightarrow\left(\mathrm{H}_{2} \mathrm{SO}_{4}\right)_{2} \cdot\left(\mathrm{CH}_{3}\right)_{2} \mathrm{NH} \cdot\left(\mathrm{H}_{2} \mathrm{O}\right)_{4} \\
2 \mathrm{H}_{2} \mathrm{SO}_{4}+\left(\mathrm{CH}_{3}\right)_{2} \mathrm{NH}+5 \mathrm{H}_{2} \mathrm{O} \rightarrow\left(\mathrm{H}_{2} \mathrm{SO}_{4}\right)_{2} \cdot\left(\mathrm{CH}_{3}\right)_{2} \mathrm{NH} \cdot\left(\mathrm{H}_{2} \mathrm{O}\right)_{5}\end{array}$ & $\begin{array}{r}-59.09 \\
-70.88 \\
-80.68 \\
-97.56 \\
-110.90 \\
-120.15\end{array}$ & $\begin{array}{r}-62.78 \\
-73.88 \\
-81.12 \\
-99.36 \\
-111.20 \\
-118.74\end{array}$ & $\begin{array}{r}-76.61 \\
-111.48 \\
-146.83 \\
-183.84 \\
-218.66 \\
-253.70\end{array}$ & $\begin{array}{l}-39.94 \\
-40.64 \\
-37.35 \\
-44.55 \\
-46.00 \\
-43.10\end{array}$ \\
\hline
\end{tabular}

As expected from previous studies (Kurtén et al., 2008), in the absence of water molecules, dimethylamine enhances the addition of another sulfuric acid to the cluster much more effectively than ammonia. Adding water molecules complicates the picture, as the number of possible bonding patterns in the clusters increases.

At first sight, the relative order of the free energy changes $\Delta G$ for the clusters with one water molecules might seem surprising, since the acid addition energies of dimethylamine- and ammonia-containing clusters are predicted to be very similar. The qualitative shape of the curves can, however, be explained by structural factors. The ad- dition of another acid to the cluster containing one sulfuric acid, one ammonia and one water is predicted to promote a proton transfer reaction from one of the acids to ammonia, leading to a much stronger bonding and thus a strongly negative free energy change $\Delta G$ value. For the cluster containing one sulfuric acid, one water and one dimethylamine, a corresponding increase in bonding strength can not take place, as our calculations predict proton transfer to have occurred already for the one-acid case. In addition, since the dimethylammonium ion can only form two hydrogen bonds (whereas the ammonium ion can in principle form four, though in practice usually only three), adding another acid to 
a)

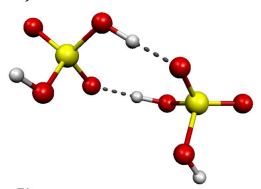

d)

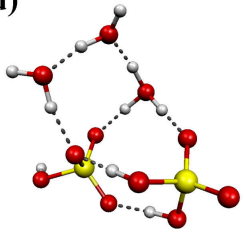

b)

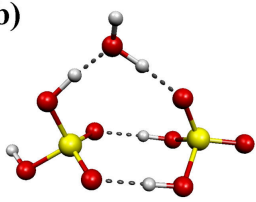

e)

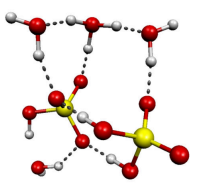

c)

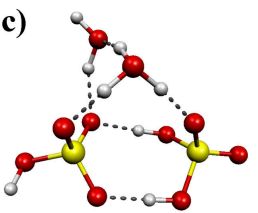

f)

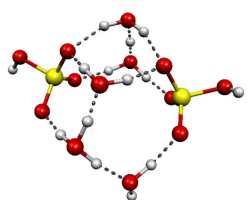

Fig. 4. The most stable structures with respect to the formation free energy $\Delta G$ (at $T=298.15 \mathrm{~K}$ and $P=1 \mathrm{~atm}$ ) for clusters consisting of two sulfuric acids and 0-5 water molecules: (a) $\left(\mathrm{H}_{2} \mathrm{SO}_{4}\right)_{2}$, (b) $\left(\mathrm{H}_{2} \mathrm{SO}_{4}\right)_{2} \cdot \mathrm{H}_{2} \mathrm{O}$, (c) $\left(\mathrm{H}_{2} \mathrm{SO}_{4}\right)_{2} \cdot\left(\mathrm{H}_{2} \mathrm{O}\right)_{2},(\mathbf{d})\left(\mathrm{H}_{2} \mathrm{SO}_{4}\right)_{2} \cdot\left(\mathrm{H}_{2} \mathrm{O}\right)_{3},(\mathbf{e})$ $\left(\mathrm{H}_{2} \mathrm{SO}_{4}\right)_{2} \cdot\left(\mathrm{H}_{2} \mathrm{O}\right)_{4}$, (f) $\left(\mathrm{H}_{2} \mathrm{SO}_{4}\right)_{2} \cdot\left(\mathrm{H}_{2} \mathrm{O}\right)_{5}$.

the dimethylamine-acid-water cluster requires breaking one of the existing amine-water bonds (compare the b)-structures in Figs. 1 and 4, 2 and 5, and in 3 and 6).

In the clusters containing two water molecules, proton transfer already occurs with one sulfuric acid in the presence of both ammonia and dimethylamine, and our calculations predict that addition of another acid does not lead to a second proton transfer, i.e. one of the acids does not dissociate at this hydration level (see the c)-structures in Figs. 2 and 5, and in 3 and 6). In contrast, for the two-water clusters without any base molecules, the addition of the second acid causes the first proton transfer reaction (see the structure c) in Fig. 4), leading to a slight increase in stability for the plain sulfuric acid-water clusters, as can be seen from Fig. 7. Similarly to the case of sulfuric acid, dimethylamine and one water, acid addition to the dimethylamine-containing two-water cluster is made relatively less favorable by the need to break one of the existing amine-water hydrogen bonds. Thus, all three free energy values for acid addition to the two-water clusters are relatively similar.

Addition of an acid to the three-water clusters leads to a second proton transfer for the ammonia- and aminecontaining structures, again increasing the difference between base-containing and plain sulfuric acid clusters (see the d)-structures in Figs. 4-6). Furthermore, for clusters containing three or more water molecules, the relative advantage (with respect to acid addition) of ammonia-containing clusters due to the greater number of $\mathrm{H}$-bonds formed by $\mathrm{NH}_{4}^{+}$ compared to $\left(\mathrm{CH}_{3}\right)_{2} \mathrm{NH}_{2}^{+}$has disappeared, as both molecules are fully "saturated" by $\mathrm{H}$-bonds already in the one-acid clusters. Thus, the greater basicity of dimethylamine (which leads to a greater stabilization of the formed ion pairs) is able to dominate the formation energetics, and for extensively hydrated clusters, dimethylamine enhances sulfuric acid addition much more effectively than ammonia.

a)

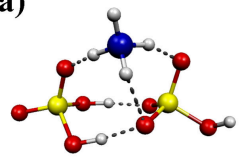

d)

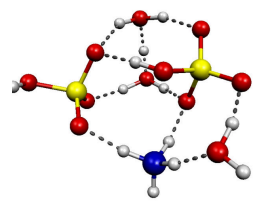

b)

e)
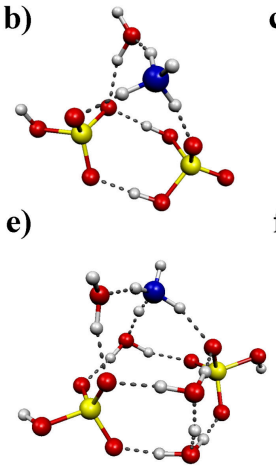

c)

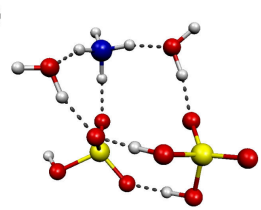

f)

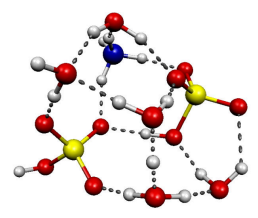

Fig. 5. The most stable structures with respect to the formation free energy $\Delta G$ (at $T=298.15 \mathrm{~K}$ and $P=1 \mathrm{~atm}$ ) for clusters consisting of two sulfuric acids with ammonia and $0-5$ water molecules: (a) $\left(\mathrm{H}_{2} \mathrm{SO}_{4}\right)_{2} \cdot \mathrm{NH}_{3}$, (b) $\left(\mathrm{H}_{2} \mathrm{SO}_{4}\right)_{2} \cdot \mathrm{NH}_{3} \cdot \mathrm{H}_{2} \mathrm{O}$, (c) $\left(\mathrm{H}_{2} \mathrm{SO}_{4}\right)_{2} \cdot \mathrm{NH}_{3} \cdot\left(\mathrm{H}_{2} \mathrm{O}\right)_{2}$, (d) $\left(\mathrm{H}_{2} \mathrm{SO}_{4}\right)_{2} \cdot \mathrm{NH}_{3} \cdot\left(\mathrm{H}_{2} \mathrm{O}\right)_{3}$, (e) $\left(\mathrm{H}_{2} \mathrm{SO}_{4}\right)_{2} \cdot \mathrm{NH}_{3} \cdot\left(\mathrm{H}_{2} \mathrm{O}\right)_{4}$, (f) $\left(\mathrm{H}_{2} \mathrm{SO}_{4}\right)_{2} \cdot \mathrm{NH}_{3} \cdot\left(\mathrm{H}_{2} \mathrm{O}\right)_{5}$.

As an interesting detail, our calculations predict that in the cluster of one acid and one dimethylamine with five waters, also the other proton of the acid is at least partly transferred, thus leading to the formation of a sulfate double-ion $\mathrm{SO}_{4}^{2-}$ (cf. structure f) in Fig. 3). This behavior is not observed in other clusters. This might be due to the fact that the cluster in question is relatively the most basic and extensively hydrated one. This implies that one might expect sulfate formation in extensively hydrated clusters of two acids and two amines. Also, the addition of the second acid to the structure of one acid, amine and five waters causes rearrangements in the bonding patterns, leading to a somewhat less negative formation energy.

In a recent first-principles molecular dynamics (FPMD) study (Anderson et al., 2008) involving 1-2 sulfuric acids with 6 water molecules and a collection of bases (including ammonia and methylamine), it was concluded that in the clusters containing two sulfuric acids, proton transfer will always take place, whereas in the clusters containing only a single sulfuric acid, the transfer will not happen, even in the presence of ammonia (though proton transfer was predicted to happen in the presence of methylamine or pyrimidine). The first conclusion regarding the two-acid clusters is in accord with our results presented here, but the latter is contradictory: our calculations predict deprotonation in the plain single-acid clusters already with three waters, and in the clusters of single acid and ammonia with two waters or more (cf. Figs. 1-2).

In Anderson et al. (2008), the difference between FPMD results and previous quantum chemistry studies (where minimum-energy geometries were used, as here) was attributed to dynamic effects. Test calculations on $\mathrm{H}_{2} \mathrm{SO}_{4} \cdot\left(\mathrm{H}_{2} \mathrm{O}\right)_{5}$ clusters at the BLYP/TZVPP level (corresponding to the method used in the FPMD study) tentatively support this conclusion, as the minimum-energy geometry 


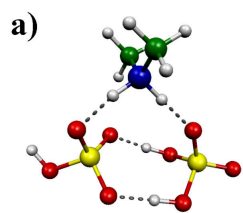

d)

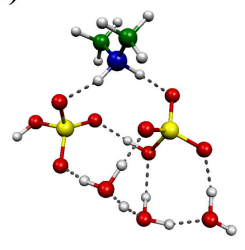

c)

e)
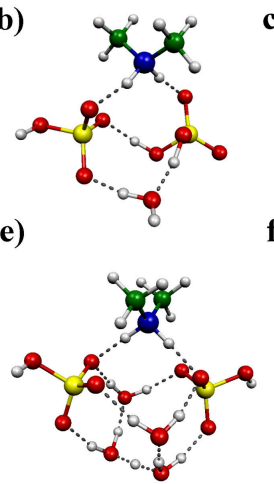

f)

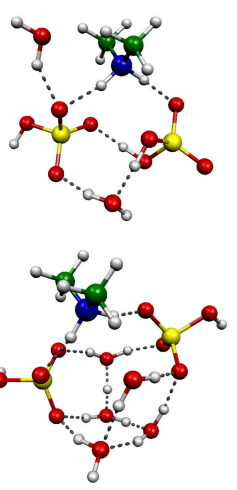

Fig. 6. The most stable structures with respect to the formation free energy $\Delta G$ (at $T=298.15 \mathrm{~K}$ and $P=1 \mathrm{~atm}$ ) for clusters consisting of two sulfuric acids with dimethylamine and 0-5 water molecules: (a) $\left(\mathrm{H}_{2} \mathrm{SO}_{4}\right)_{2} \cdot\left(\mathrm{CH}_{3}\right)_{2} \mathrm{NH}$, (b) $\left(\mathrm{H}_{2} \mathrm{SO}_{4}\right)_{2} \cdot\left(\mathrm{CH}_{3}\right)_{2} \mathrm{NH} \cdot \mathrm{H}_{2} \mathrm{O}$, (c) $\left(\mathrm{H}_{2} \mathrm{SO}_{4}\right)_{2} \cdot\left(\mathrm{CH}_{3}\right)_{2} \mathrm{NH} \cdot\left(\mathrm{H}_{2} \mathrm{O}\right)_{2}$, (d) $\left(\mathrm{H}_{2} \mathrm{SO}_{4}\right)_{2} \cdot\left(\mathrm{CH}_{3}\right)_{2} \mathrm{NH}$. $\left(\mathrm{H}_{2} \mathrm{O}\right)_{3}$, (e) $\left(\mathrm{H}_{2} \mathrm{SO}_{4}\right)_{2} \cdot\left(\mathrm{CH}_{3}\right)_{2} \mathrm{NH} \cdot\left(\mathrm{H}_{2} \mathrm{O}\right)_{4}$, (f) $\left(\mathrm{H}_{2} \mathrm{SO}_{4}\right)_{2}$. $\left(\mathrm{CH}_{3}\right)_{2} \mathrm{NH} \cdot\left(\mathrm{H}_{2} \mathrm{O}\right)_{5}$.

at this level is found to contain an ion pair, whereas the FPMD simulations at the same level predict no proton transfer even for the $\mathrm{H}_{2} \mathrm{SO}_{4} \cdot\left(\mathrm{H}_{2} \mathrm{O}\right)_{6}$ cluster. However, it should be noted that previous quantum chemistry studies (Kurtén et al., 2007b; Nadykto et al., 2007) predict an earlier onset of proton transfer than e.g. the method used here, and that the difference between different quantum chemical energy models is likely of the same order of magnitude as the difference between static and dynamic simulations. Furthermore, in our geometry optimizations on clusters without base molecules, the protonation state of the sulfuric acid molecules (or corresponding hydrogensulfate ions) typically did not change, but remained the same as in the initial guess geometry. Thus, intact molecules remained intact, and ion pairs remained as ion pairs, regardless of the global minimum-energy geometry of the stoichiometry in question. This implies that the phase-space sampling of the FPMD simulation may not be complete (as cautioned in Anderson et al., 2008), and that simulations starting from ion-pair geometries might have led to different conclusions.

Nevertheless, the possibility that dynamic effects act to diminish the extent of proton transfer in small clusters is intriguing, and should be kept in mind during the analysis of our results. In terms of the acid addition energetics presented above, the lack of proton transfer in all $\mathrm{H}_{2} \mathrm{SO}_{4} \cdot \mathrm{NH}_{3} \cdot\left(\mathrm{H}_{2} \mathrm{O}\right)_{\mathrm{X}}$ $(\mathrm{x}<7)$ clusters suggested in Anderson et al. (2008) would serve to make the addition of acid molecules to ammoniacontaining clusters somewhat more favorable than predicted here for $x \geq 2$. On the other hand, the lack of a second proton transfer (from acid to water) in all two-acid clusters (as predicted in Anderson et al., 2008) would correspondingly make the addition of acid molecules to both ammonia and dimethylamine-containing clusters somewhat less favor-

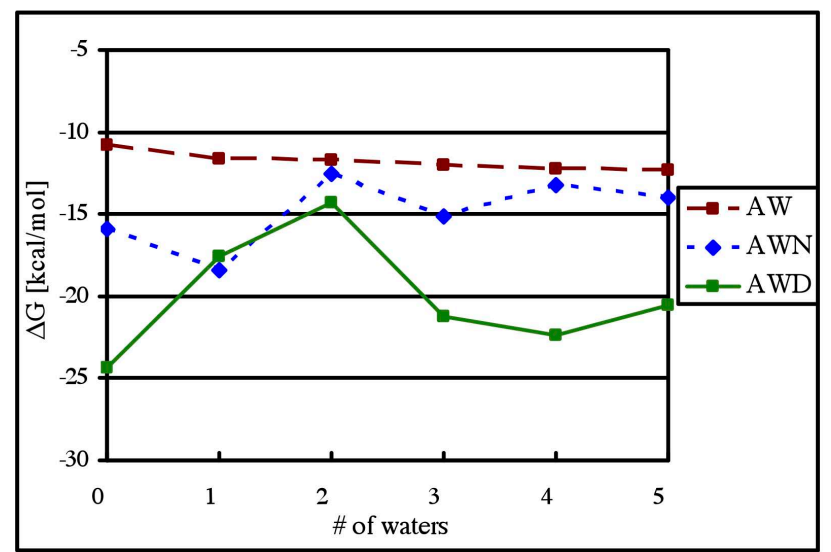

Fig. 7. The free energy change $\Delta G$ of addition of one $\mathrm{H}_{2} \mathrm{SO}_{4}$ molecule to the clusters containing one sulfuric acid and 0-5 water molecules. AW: clusters with only sulfuric acid and water; AWN: clusters containing one sulfuric acid and an ammonia molecule; AWD: clusters containing one sulfuric acid and a dimethylamine molecule.

able for most clusters with $x \geq 3$. For the dimethylaminecontaining five-water cluster, acid addition might again be somewhat more favorable than predicted here, since the partial formation of $\mathrm{SO}_{4}^{2-}$ could be cancelled out by dynamic effects. For the dry clusters (i.e. those containing no water), the possible role of dynamic effects will not change the conclusions, as both methods (the static calculations presented here and FPDM in Anderson et al., 2008) are in agreement concerning the degree of proton transfer. As discussed in the next section, the atmospheric relevance of our results is primarily related to these clusters.

\subsection{Hydration}

The pattern of acid addition energetics seen in Fig. 7 is likely to have interesting implications for the relative enhancement of nucleation by amines compared to ammonia as a function of relative humidity. To draw further conclusions, we need to know how the number of water molecules in the clusters is affected by the relative humidity. Towards this end, we have calculated the equilibrium hydrate distributions, i.e. the equilibrium fractions of the cluster "cores" (the non-aqueous part of the clusters consisting of sulfuric acid and base molecules) having a different number of water molecules attached to them.

The number concentration of a hydrate, e.g. one $\mathrm{H}_{2} \mathrm{SO}_{4}$ with $n$ water molecules can be given as (Noppel et al., 2002)

$\rho(1, n)=K_{1} K_{2} \cdots K_{n}\left(\frac{\rho_{\text {water }}^{\text {free }}}{\rho}\right)^{n} \rho_{\mathrm{H}_{2} \mathrm{SO}_{4}}^{\text {free }}$,

where $K_{m}$ are the equilibrium constants

$K_{m}=e^{-\frac{\Delta G_{m}}{R T}}$ 
with $\Delta G_{m}$ the formation free energy of an $m$-hydrate formed from one water molecule and ( $m-1)$-hydrate, $T$ the temperature and $R$ the molar gas constant, all in SI units. The free monomer concentration of water is approximately given by

$\rho_{\text {water }}^{\text {free }}=\frac{S}{k_{\mathrm{B}} T} P_{\text {water }}^{\text {eq }}$,

where $S$ is the saturation ratio (here $S$ is defined as a ratio of the proper partial pressure of the water vapor to the saturation vapor pressure and thus the relative humidity is defined as $\mathrm{RH}=100 \% \times S), k_{\mathrm{B}}$ the Boltzmann constant in SI units, $T$ the temperature in Kelvins and $P_{\text {water }}^{\text {eq }}$ the saturation vapor pressure of water (Seinfeld and Pandis, 1998) in Pascals. This is a valid approximation, since the hydration of the small clusters does not significantly affect the amount of free water molecules available, as there are always several orders of magnitude more water molecules in the atmosphere than any other condensing species.

The reference concentration $\rho$ can be given in terms of some reference pressure $P$ (here $P=1 \mathrm{~atm}$ ), the Boltzmann constant $k_{\mathrm{B}}$ and the temperature $T$ as

$\rho=\frac{P}{k_{\mathrm{B}} T}$.

As we are interested in the relative fractions of the different hydrates of the cluster cores, the absolute concentrations of the nonhydrated core clusters are not needed. For example, in the particular case of hydration of one sulfuric acid molecule, the concentration of free sulfuric acid $\rho_{\mathrm{H}_{2} \mathrm{SO}_{4}}^{\text {free }}$ is eventually cancelled out from the final expressions. Thus, the relative concentration of some $m$-hydrate in this case is then given as

$$
\begin{aligned}
\frac{\rho(1, m)}{\rho_{\mathrm{H}_{2} \mathrm{SO}_{4}}^{\text {total }}} & =\frac{\rho(1, m)}{\rho(1,0)+\rho(1,1)+\cdots+\rho(1, n)} \\
& =\frac{K_{1} K_{2} \cdots\left(S \frac{P_{\text {water }}^{\mathrm{eq}}}{P}\right)^{m}}{1+K_{1} S \frac{P_{\text {water }}^{\mathrm{eq}}}{P}+\cdots+K_{1} K_{2} \cdots K_{n}\left(S \frac{P_{\text {water }}^{\mathrm{eq}}}{P}\right)^{n}},
\end{aligned}
$$

where the hydration level $m$ can take values between 1 and $n, n$ being the amount of water molecules in the most extensively hydrated case.

In all hydrate distribution calculations, we assume equilibrium conditions, and furthermore that all the sulfuric acid is contained in the specific hydrates whose distribution is under study. For instance, while calculating hydrate distributions for clusters of one sulfuric acid molecule and no base molecules, we ignore all the other sulfuric acid-containing clusters. Since the purpose of this calculation is to estimate the hydration of different cluster "cores", this approach is justifiable.

To assess the extent of hydration in different circumstances, we calculated the hydrate distributions for the plain sulfuric acid clusters (one and two acids) and for the clusters containing either one or two acids together with one ammonia or dimethylamine molecule, at different relative humidities (RH) and temperatures. Assuming that the enthalpy and entropy of cluster formation are fairly constant with respect to the temperature, one can approximate the Gibbs formation free energies at different temperatures based on the values calculated at $298.15 \mathrm{~K}$ (and given in Table 2) as $\Delta G(T)=\Delta H(298.15 K)-T \Delta S(298.15 K)$. The temperature sensitivity of the hydrate distributions with constant relative humidity was observed to be weak. This is most likely due to the opposed temperature-behaviour of the formation free energy and the absolute water concentration. For instance, lowering the temperature shifts the Gibbs free energies into more negative direction, and as such implies more hydration. However, decreasing temperature also diminishes the absolute water concentration, and to a large extent these two competing effects cancel out, thus leaving the hydrate distributions reasonably temperature-independent.

The sensitivity of the hydrate distributions to the relative humidity is more noticeable and thus worth a more detailed analysis. The general trend in all cases is more extensive hydration with the growing $\mathrm{RH}$, as expected, although all the clusters do pose a different characteristics of hydration. The hydrate distributions for all the studied core clusters are presented in Figs. 8-10 for three values of the relative humidity $(20 \%, 50 \%$ and $80 \%)$ with a constant temperature of $298.15 \mathrm{~K}$. This temperature does not represent the conditions of the whole troposphere, but as mentioned, the hydrate distribution at constant RH does not significantly change upon temperature changes of a few tens of degrees.

The plain sulfuric acid clusters - both the one- and twoacid clusters - were most extensively hydrated, as can be seen in Fig. 8. At most tropospherically reasonable conditions (relative humidity and temperature), the total concentration of sulfuric acid in these clusters was dispersed mainly in the mono- and dihydrates. With increasing $\mathrm{RH}$, the peak of the distribution moves from unhydrated clusters to dihydrates in such a manner that unhydrated clusters dominate only when the relative humidity is less that ten per cent. The hydrate distributions for sulfuric acid calculated here are fairly consistent with earlier high-level quantum chemistry studies (Kurtén et al., 2007a) as well with experimental measurements (Hanson and Eisele, 2000). However, it might be possible that the methods used in this study underestimate the extent of hydration slightly, at least in comparison with Kurtén et al. (2007a) and Hanson and Eisele (2000).

The hydration patterns of clusters containing one sulfuric acid with ammonia and one sulfuric acid with dimethylamine are more interesting, as Fig. 9 reveals. The dimer complex of sulfuric acid and ammonia hydrates quite effectively at higher RH. More than $50 \%$ of the clusters are hydrated already with the relative humidities greater than $45 \%$. As the $\mathrm{RH}$ grows, the peak of the distribution shifts through dihydrate to trihydrate $(\mathrm{RH}>80 \%)$, bypassing almost completely the monohydrate. This behavior can probably be explained by considering the structure of the $\mathrm{H}_{2} \mathrm{SO}_{4} \cdot \mathrm{NH}_{3} \cdot \mathrm{H}_{2} \mathrm{O}$ cluster: here the acid is still intact, as opposed to the two- and three-water cases where the acid has dissociated, leading to 

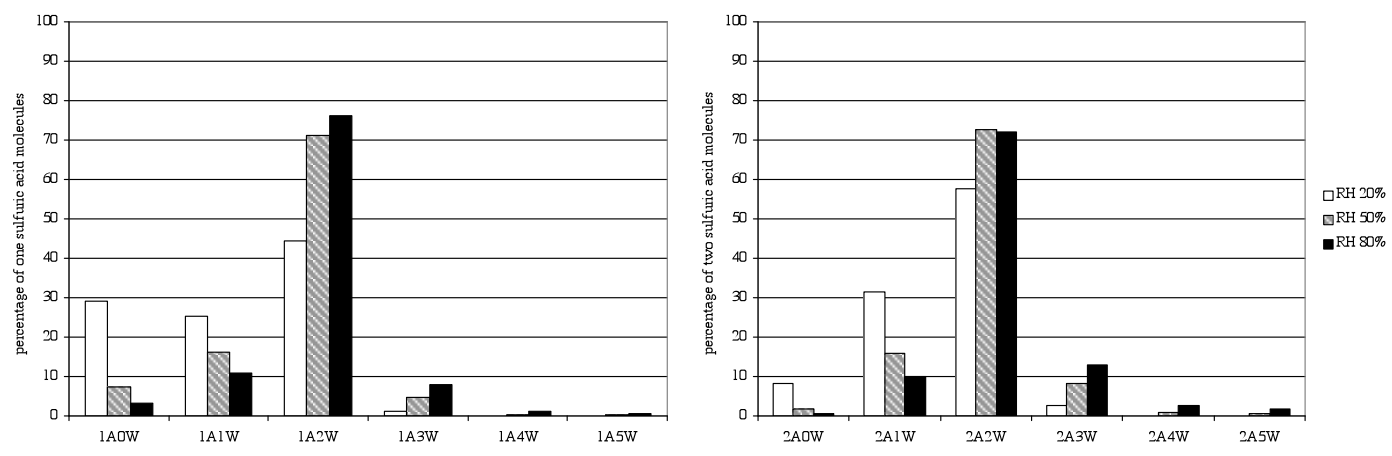

Fig. 8. Hydrate distributions of clusters with one sulfuric acid molecule (left) and clusters with two sulfuric acid molecules (right) at three different relative humidities. $1 \mathrm{AxW} \equiv \mathrm{H}_{2} \mathrm{SO}_{4} \cdot\left(\mathrm{H}_{2} \mathrm{O}\right)_{\mathrm{X}}$ and $2 \mathrm{AxW} \equiv\left(\mathrm{H}_{2} \mathrm{SO}_{4}\right)_{2} \cdot\left(\mathrm{H}_{2} \mathrm{O}\right)_{\mathrm{X}}$. In all cases $T=298.15 \mathrm{~K}$.
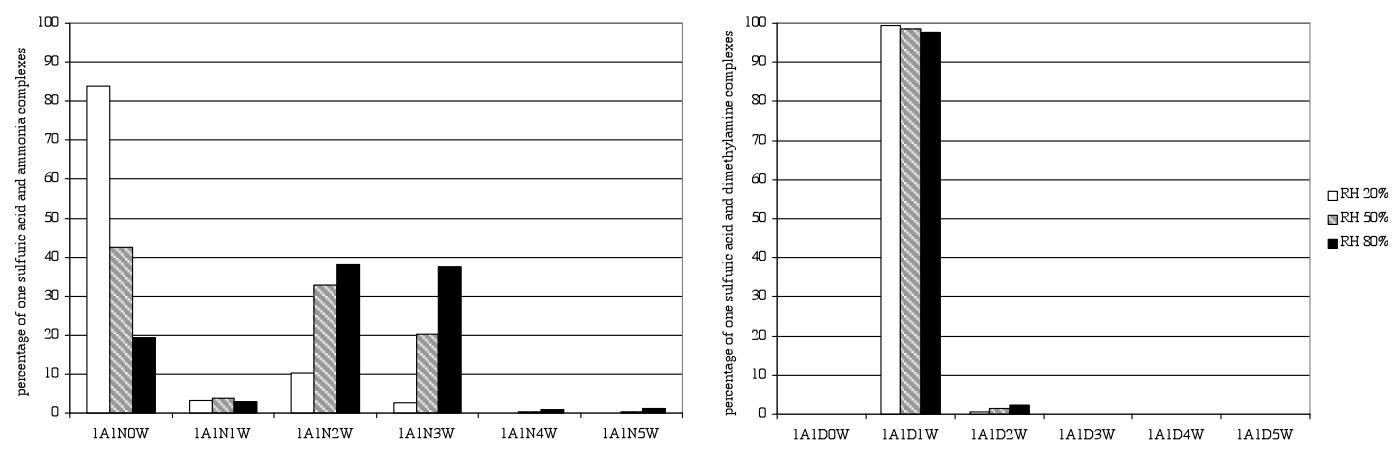

Fig. 9. Hydrate distributions of clusters with one sulfuric acid and ammonia (left) and clusters with one sulfuric acid and dimethylamine (right) at three different relative humidities. $1 \mathrm{~A} 1 \mathrm{NxW} \equiv \mathrm{H}_{2} \mathrm{SO}_{4} \cdot \mathrm{NH}_{3} \cdot\left(\mathrm{H}_{2} \mathrm{O}\right)_{\mathrm{x}}$ and $1 \mathrm{~A} 1 \mathrm{DxW} \equiv \mathrm{H}_{2} \mathrm{SO}_{4} \cdot\left(\mathrm{CH}_{3}\right)_{2} \mathrm{NH} \cdot\left(\mathrm{H}_{2} \mathrm{O}\right)_{\mathrm{x}}$. In all cases $T=298.15 \mathrm{~K}$.

stronger bonding (cf. the acid addition discussion above). On the other hand, the hydrate distribution of the sulfuric acid and dimethylamine complex is virtually static with respect to the changes in relative humidity and temperature. The peak of the cluster distribution is in this case the monohydrate with a share of practically 100 per cent (cf. right panel of the Fig. 9). This would suggest that the clusters consisting of one sulfuric acid and dimethylamine will always bond with just one water molecule regardless of how much water actually is available. This also implies that at lower values of relative humidity $(\mathrm{RH}<45 \%)$, a single sulfuric acid molecule bound to dimethylamine binds water slightly better than a single sulfuric acid molecule bound to ammonia. One reason for this might be the attractive dipole-dipole interaction between the acid-amine cluster $\left(\left(\mathrm{CH}_{3}\right)_{2} \mathrm{NH}_{2}^{+} \cdot \mathrm{HSO}_{4}^{-}\right)$ and the water molecule, and the subsequent strong hydrogen bonding (cf. the acid addition discussion above and the structure b) in Fig. 3). In the case of sulfuric acid and ammonia, there is no strong dipole-dipole interaction between the cluster and water, and as mentioned, the portion of acid-ammonia monohydrate of the total acid concentration is negligible.
The hydrate distributions of the two-acid clusters with ammonia and dimethylamine have yet different characteristics, as is evident from the Fig. 10. The ammonia-containing distribution peaks at the monohydrate, whereas dimethylaminecontaining clusters stay almost completely dry. The behavior of the former is in accordance with the acid addition discussion: the complex of two sulfuric acids, ammonia and one water molecule is the most strongly bound of all the two acid-ammonia clusters considered in this study. In addition to the first proton transfer reaction occurring at this hydration level, this particular structure has a convenient symmetry with respect to the possible hydrogen bonds ammonia can form to stabilize the cluster, i.e. ammonia is able to bind the two acids and water strongly together (cf. structure b) in Fig. 5). Similar reasoning explains also the two-acid distribution with dimethylamine since the most energetically stable cluster is the unhydrated one. Structural reasons for this are compelling: dimethylamine can bind two acids together due to its ability to a form maximum of two hydrogen bonds (cf. structure a) in Fig. 6). Including water molecules to this complex means breaking some of the existing, "strong" hydrogen bonds, and it seems that the new bonding patterns compensate this loss of binding energy only after the second 

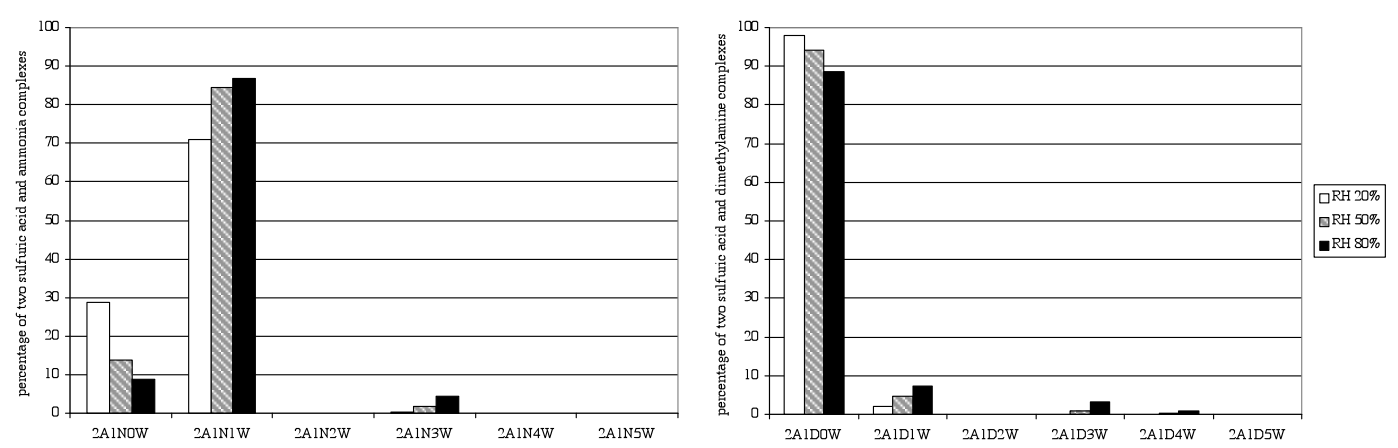

Fig. 10. Hydrate distributions of clusters with two sulfuric acid and ammonia (left) and clusters with two sulfuric acid and dimethylamine (right) at three different relative humidities. $2 \mathrm{~A} 1 \mathrm{NxW} \equiv\left(\mathrm{H}_{2} \mathrm{SO}_{4}\right)_{2} \cdot \mathrm{NH}_{3} \cdot\left(\mathrm{H}_{2} \mathrm{O}\right)_{\mathrm{X}}$ and $2 \mathrm{~A} 1 \mathrm{DxW} \equiv\left(\mathrm{H}_{2} \mathrm{SO} 4\right)_{2} \cdot\left(\mathrm{CH}_{3}\right)_{2} \mathrm{NH} \cdot\left(\mathrm{H}_{2} \mathrm{O}\right)_{\mathrm{X}} \cdot \mathrm{In}$ all cases $T=298.15 \mathrm{~K}$.

proton transfer happens. For the second proton transfer to take place, according to our calculations, there must be three or more water molecules in the cluster (cf. the acid addition discussion). Consequently, this requires very high supersaturations. In order to have the fraction of the hydrated clusters compatible to the unhydrated one, a relative humidity on the order of $250 \%$ is required. This very strongly suggests that the two-acid clusters with dimethylamine will remain unhydrated in all tropospherically relevant conditions.

It should be mentioned that the details of the hydrate distributions are quite sensitive to the vibrational frequencies and thus to the particular scaling used, since the inaccuracies in thermochemistry affect the hydrate distribution cumulatively. However, perhaps the most important result here, the reluctance of the amine-containing two-acid cluster to hydrate, did not quantitatively change with different vibrational scaling approaches.

\subsection{Atmospheric relevance}

Of course, the formation energetics do not solely govern the cluster distributions in the atmosphere. Often the absolute and relative concentrations of the species in question have a large and more decisive role. The effect of concentration on the cluster distributions can be estimated with the law of mass balance (as done above for the case of water concentrations, see Eq. 6). For example, for the most probable twoacid clusters with different bases, i.e. two sulfuric acids with dimethylamine and no waters and two acids with ammonia and one water molecule (at $T=298.15 \mathrm{~K}$ and $\mathrm{RH}=50 \%$, cf. discussion above and Fig. 10), the ratio of concentrations can be given as:

$$
\frac{\left[\left(\mathrm{H}_{2} \mathrm{SO}_{4}\right)_{2} \cdot\left(\mathrm{CH}_{3}\right)_{2} \mathrm{NH}\right]}{\left[\left(\mathrm{H}_{2} \mathrm{SO}_{4}\right)_{2} \cdot \mathrm{NH}_{3} \cdot \mathrm{H}_{2} \mathrm{O}\right]}=\frac{\left[\left(\mathrm{CH}_{3}\right)_{2} \mathrm{NH}\right]}{\left[\mathrm{NH}_{3}\right]} \frac{e^{-\frac{\Delta \Delta G}{R T}}}{\left[\mathrm{H}_{2} \mathrm{O}\right]},
$$

where $\Delta \Delta G$ is the difference in the formation free energies of the two clusters, that is,

$$
\begin{aligned}
\Delta \Delta G \equiv \Delta G\left(\left(\mathrm{H}_{2} \mathrm{SO}_{4}\right)_{2} \cdot\left(\mathrm{CH}_{3}\right)_{2} \mathrm{NH}\right)-\Delta G\left(\left(\mathrm{H}_{2} \mathrm{SO}_{4}\right)_{2}\right. \\
\left.\cdot \mathrm{NH}_{3} \cdot \mathrm{H}_{2} \mathrm{O}\right),
\end{aligned}
$$

$\Delta G(\mathrm{X})$ being the formation free energy of the complex $\mathrm{X}, R$ is the molar gas constant and $T$ the temperature in Kelvins. An expression for the concentration of water can be obtained from Eqs. (4) and (5) as

$\left[\mathrm{H}_{2} \mathrm{O}\right]=\frac{P_{\mathrm{water}}^{\mathrm{eq}}}{P} S$

where $P_{\text {water }}^{\text {eq }}$ is the saturation vapor pressure of water, $P$ reference pressure and $S$ the saturation ratio.

There is typically more ammonia in the atmosphere than there is dimethylamine, but an accurate quantitative assessment is difficult due to the small number of amine measurements. The relative abundance of different amines compared to ammonia also varies significantly according to specific environmental conditions. For example, Sellegri et al. (2005) have measured almost the same atmospheric concentrations for trimethylamine and ammonia in boreal forest at SMEAR II station (Hari and Kulmala, 2005), whereas in a recent study in marine environment (Müller et al., 2009), concentrations of diethyl- and dimethylamine were observed to be three orders of magnitude smaller than that of ammonium, although the amines still contributed non-negligibly to the total detected nitrogen. However, in another marine environment study during high biological activity (Facchini et al., 2008), the same amines were measured to be considerably abundant in the sub-micrometer aerosol particles, again indicating their possible importance in the secondary organic aersol formation. Altogether, probably a realistic estimate for the difference in the concentrations is between 1 to 4 orders of magnitude. Using the formation free energies collected in the Table 2 with the Eq. (7), one can obtain qualitative estimates for the ratio of concentrations of $\left(\mathrm{H}_{2} \mathrm{SO}_{4}\right)_{2} \cdot\left(\mathrm{CH}_{3}\right)_{2} \mathrm{NH}$ to $\left(\mathrm{H}_{2} \mathrm{SO}_{4}\right)_{2} \cdot \mathrm{NH}_{3} \cdot \mathrm{H}_{2} \mathrm{O}$. These results are presented in Table 3. 
Table 3. Ratio of concentrations of clusters of two sulfuric acids with one dimethylamine to two sulfuric acids with one ammonia and one water, as a function of the dimethylamine to ammonia concentration ratio. Equilibrium steady-state conditions are assumed and $T=298.15 \mathrm{~K}, P=1 \mathrm{~atm}$ and $\mathrm{RH}=50 \%$.

\begin{tabular}{lr}
\hline$\left[\left(\mathrm{CH}_{3}\right)_{2} \mathrm{NH}\right] /\left[\mathrm{NH}_{3}\right]$ ratio & {$\left[\left(\mathrm{H}_{2} \mathrm{SO}_{4}\right)_{2} \cdot\left(\mathrm{CH}_{3}\right)_{2} \mathrm{NH}\right] /$} \\
\hline 1 & {$\left[\left(\mathrm{H}_{2} \mathrm{SO}_{4}\right)_{2} \mathrm{NH}_{3} \mathrm{H}_{2} \mathrm{O}\right]$ ratio } \\
0.1 & $1.2 \times 10^{10}$ \\
0.01 & $1.2 \times 10^{9}$ \\
0.001 & $1.2 \times 10^{8}$ \\
0.0001 & $1.2 \times 10^{7}$ \\
0.00001 & $1.2 \times 10^{6}$ \\
& $1.2 \times 10^{5}$ \\
\hline
\end{tabular}

Table 3 reveals that dimethylamine-containing two-acid clusters would clearly dominate the cluster distribution, even when the (gas-phase) amine concentration is only a thousandth or less of the ammonia concentration. Of course, the results in the Table 3 should be taken only as a rough estimate due to several approximations made in the calculation, as already mentioned during the discussion on hydration. Nevertheless, under the conditions where ammonia and the amine are competing as a nucleation enhancing agents, the aminecontaining clusters are likely to prevail, at least until all the available amine is consumed in the process.

The atmospheric relevance of the results presented in this study is tied to the overall significance of ternary nucletion in the atmosphere, which is still a subject of ongoing research. According to some authors, the role of ternary nucleation of sulfuric acid, ammonia and water is negligible (Yu, 2006), whereas other approaches (Korhonen et al., 1999; Napari et al., 2002; Anttila et al., 2005) give varying predictions for the ternary nucleation rates. Jung et al. (2009) have shown that the ternary nucleation model of Napari et al. (2002) can be used as a basis of successful prediction of particle formation rates in Pittsburg, US.

However, rigorous ab initio based nucleation parameterizations for atmospherically relevant compounds are still to be constructed and a subtle caution should be maintained while drawing conclusions in the light of the current theoretical results for the nucleation rates. On the other hand, nucleation rates do not necessarily reveal all the details: aerosol particle formation might be a two-step process, involving formation of very stable molecular clusters with diameters below two nanometers and their subsequent growth to observable sizes under favourable conditions (Kulmala et al., 2000, 2007). In this scenario, amines, such as dimethylamine, are particularly good candidates for the nucleation enhancement and stabilization of the small atmospheric clusters.

\section{Conclusions}

We have investigated the hydration (by up to five water molecules) of clusters consisting of 1-2 sulfuric acid molecules with either an ammonia or a dimethylamine molecule by computational means. The formation energetics and structures of the abovementioned clusters were explored using quantum chemistry. Also, the equilibrium hydrate distributions for the plain one- and two-acid clusters, single acid clusters with either ammonia or dimethylamine, and clusters of two sulfuric acids with either one of the bases were calculated.

The results indicate that (a) dimethylamine enhances the growth of the cluster along the sulfuric acid axis much more effectively than ammonia when the number of water molecules in the cluster is either zero or greater than two, and (b) in all tropospherically reasonable conditions the twoacid clusters with dimethylamine remain almost completely unhydrated. Thus, it is very likely that dimethylamine assists sulfuric acid nucleation much more efficiently than ammonia in all tropospherical circumstances. However, calculations on larger clusters (containing both more acids and multiple bases) are still required to determine the size of the critical cluster in sulfuric acid - dimethylamine nucleation.

Acknowledgements. We thank the computing resources of CSC IT Center for Science Ltd in Espoo, Finland, for computing time. This research was supported by the Academy of Finland (project numbers 1127372, 118433, 203675 and Center of Excellence program, project number 1118615) and OPGC (Observation de Physique de Globe de Clermont Ferrand).

Edited by: A. Wiedensohler

\section{References}

Ahlrichs, R., Bär, M., Horn, H., and Kölmel, C.: Electronic structure calculations on workstation computers: The program system turbomole, Chem. Phys. Lett., 162, 165-169, 1989.

Allison, I., Bindoff, N. L., Bindschadler, R. A., et al.: The Copenhagen Diagnosis: Updating the world on the Latest Climate Science, The University of New South Wales Climate Change Research Centre (CCRC), Sydney, Australia, 60 pp., 2009.

Al Natsheh, A., Nadykto, A. B., Mikkelsen, K. V., Yu, F., and Ruuskanen, J.: Sulfuric acid and sulfuric acid hydrates in the gas phase: a DFT investigation, J. Phys. Chem. A, 108, 8914-8929, 2004.

Anttila, T., Vehkamäki, H., Napari, I., and Kulmala, M.: Effect of ammonium bisulphate formation on atmospheric water-sulphuric acid-ammonia nucleation, Boreal Env. Res., 10, 511-523, 2005.

Anderson, K. E., Siepmann, J. I., McMurry, P. H., and VandeVondele, J.: Importance of the number of acid molecules and the strength of the base for double-ion formation in $\left(\mathrm{H}_{2} \mathrm{SO}_{4}\right)_{\mathrm{m}}$. Base $\cdot\left(\mathrm{H}_{2} \mathrm{O}\right)_{6}$ clusters, J. Am. Chem. Soc., 130, 14144-14147, 2008.

Ball, S. M., Hanson, D. R., Eisele, F. L., and McMurry, P. H.: Laboratory studies of particle nucleation: Initial results for $\mathrm{H}_{2} \mathrm{SO}_{4}$, 
$\mathrm{H}_{2} \mathrm{O}$, and $\mathrm{NH}_{3}$ vapors, J. Geophys. Res. D, 104, 23709-23718, 1999.

Bandy, A. R. and Ianni, J. C.: Study of the hydrates of $\mathrm{H}_{2} \mathrm{SO}_{4}$ using density functional theory, J. Phys. Chem. A, 102, 6533-6539, 1998.

Barsanti, K. C., McMurry, P. H., and Smith, J. N.: The potential contribution of organic salts to new particle growth, Atmos. Chem. Phys., 9, 2949-2957, doi:10.5194/acp-9-2949-2009, 2009.

Bernholdt, D. E. and Harrison, R. J.: Large-scale correlated electronic structure calculations: the RI-MP2 method on parallel computers, Chem. Phys. Lett., 250, 477-484, 1996.

Bzdek, B. R., Ridge, D. P., and Johnston, M. V.: Amine exchange into ammonium bisulfate and ammonium nitrate nuclei, Atmos. Chem. Phys., 10, 3495-3503, doi:10.5194/acp-10-3495-2010, 2010.

Ding, C.-G., Laasonen, K., and Laaksonen, A.: Two Sulfuric Acids in Small Water Clusters, J. Phys. Chem. A, 107, 8648-8658, 2003.

Dunning Jr., T. H., Peterson, K. A., and Wilson, A. K.: Gaussian basis sets for use in correlated molecular calculations. X. The atoms aluminum through argon revisited, J. Chem. Phys., 114, 9244-9253, 2001.

Frisch, M. J., Trucks, G. W., Schlegel, H. B., Scuseria, G. E., Robb, M. A., Cheeseman, J. R., Montgomery Jr., J. A., Vreven, T., Kudin, K. N., Burant, J. C., Millam, J. M., Iyengar, S. S., Tomasi, J., Barone, V., Mennucci, B., Cossi, M., Scalmani, G., Rega, N., Petersson, G. A., Nakatsuji, H., Hada, M., Ehara, M., Toyota, K., Fukuda, R., Hasegawa, J., Ishida, M., Nakajima, T., Honda, Y., Kitao, O., Nakai, H., Klene, M., Li, X., Knox, J. E., Hratchian, H. P., Cross, J. B., Bakken, V., Adamo, C., Jaramillo, J., Gomperts, R., Stratmann, R. E., Yazyev, O., Austin, A. J., Cammi, R., Pomelli, C., Ochterski, J. W., Ayala, P. Y., Morokuma, K., Voth, G. A., Salvador, P., Dannenberg, J. J., Zakrzewski, V. G., Dapprich, S., Daniels, A. D., Strain, M. C., Farkas, O., Malick, D. K., Rabuck, A. D., Raghavachari, K., Foresman, J. B., Ortiz, J. V., Cui, Q., Baboul, A. G., Clifford, S., Cioslowski, J., Stefanov, B. B., Liu, G., Liashenko, A., Piskorz, P., Komaromi, I., Martin, R. L., Fox, D. J., Keith, T., Al-Laham, M. A., Peng, C. Y., Nanayakkara, A., Challacombe, M., Gill, P. M. W., Johnson, B., Chen, W., Wong, M. W., Gonzalez, C., and Pople, J. A.: Gaussian 03, Revision C.02, , Gaussian, Inc., Wallingford CT, 2004.

Grev, R. S., Janssen, C. L., and Schaefer III, H. F.: Concerning zero-point vibrational energy corrections to electronic energies, J. Chem. Phys., 95, 5128-5132, 1991.

Facchini, M. C., Decesari, S., Rinaldi, M., Carbone, C., Finessi, E., Mircea, M., Fuzzi, S., Moretti, F., Tagliavini, E., Ceburnis, D., and O'Dowd, C. D.: Important source of marine secondary organic aerosol from biogenic amines, Environ. Sci. Technol., 42, 9116-9121, 2008.

Hanson, D. R. and Eisele, F. L.: Diffusion of $\mathrm{H}_{2} \mathrm{SO}_{4}$ in humidified nitrogen: hydrated $\mathrm{H}_{2} \mathrm{SO}_{4}$, J. Phys. Chem. A, 104, 1715-1719, 2000.

Hari, P. and Kulmala, M.: Station for Measuring EcosystemAtmosphere Relations (SMEAR II), Boreal Env. Res., 10, 315$322,2005$.

Ianni, J. C. and Bandy, A. R.: A density functional theory study of the hydrates of $\mathrm{NH}_{3}, \mathrm{H}_{2} \mathrm{SO}_{4}$ and its implications for the forma- tion of new atmospheric particles, J. Phys. Chem. A, 103, 28012811, 1999.

Iida, K., Stolzenburg, M., McMurry, P., Dunn, M. J., Smith, J. N., Eisele, F., and Keady, P.: Contribution of ion-induced nucleation to new particle formation: Methodology and its application to atmospheric observations in Boulder, Colorado, J. Geophys. Res., 111, D23201, doi:10.1029/2006JD007167, 2006.

The Intergovernmental Panel on Climate Change: Climate Change 2007: The Physical Science Basis, Cambridge University Press, New York, USA, 2007.

Jung, J., Fountoukis, C., Adams, P. J., and Pandis, S. N.: Simulation of in-situ ultrafine particle formation in the Eastern United States using PMCAMx-UF, in: Proceedings of the 18th International Conference on Nucleation and Atmospheric Aerosols, Prague, Czech Republic, 10-14 August 2009, 338-342, 2009.

Kavouras, I. G., Mihalopoulos, N., and Stephanou, E. G.: Secondary organic aerosol formation vs. primary organic aerosol emission: in situ evidence for the chemical coupling between monoterpene acidic photooxidation products and new particle formation over forests, Environ. Sci. Technol., 33, 1028-1037, 1999.

Kazil, J., Lovejoy, E. R., Barth, M. C., and O’Brien, K.: Aerosol nucleation over oceans and the role of galactic cosmic rays, Atmos. Chem. Phys., 6, 4905-4924, doi:10.5194/acp-6-4905-2006, 2006.

Korhonen, P., Kulmala, M., Laaksonen, A., Viisanen, Y., McGraw, R., and Seinfeld, J. H.: Ternary nucleation of $\mathrm{H}_{2} \mathrm{SO}_{4}$, $\mathrm{NH}_{3}$, and $\mathrm{H}_{2} \mathrm{O}$ in the atmosphere, J. Geophys. Res., 104, 2634926353, 1999.

Kulmala, M., Pirjola, L., and Mäkelä, J. M.: Stable sulphate clusters as a source of new atmospheric particles, Nature, 404, 66-69, 2000.

Kulmala, M., Vehkamäki, H., Petäjä, T., Dal Maso, M., Lauri, A., Kerminen, V.-M., Birmili, W., and McMurry, P. H.: Formation and growth rates of ultrafine atmospheric particles: a review of observations, J. Aerosol Sci., 35, 143-176, 2004.

Kulmala, M., Lehtinen, K. E. J., and Laaksonen, A.: Cluster activation theory as an explanation of the linear dependence between formation rate of $3 \mathrm{~nm}$ particles and sulphuric acid concentration, Atmos. Chem. Phys., 6, 787-793, doi:10.5194/acp-6-787-2006, 2006.

Kulmala, M., Riipinen, I., Sipilä, M., Manninen, H. E., Petäjä, T., Junninen, H., Dal Maso, M., Mordas, G., Mirme, A., Vana, M., Hirsikko, A., Laakso, L., Harrison, R. M., Hanson, I., Leung, C., Lehtinen, K. E. J., and Kerminen, V.-M.: Toward direct measurement of atmospheric nucleation, Science, 318, 89-92, 2007.

Kulmala, M., Riipinen, I., Nieminen, T., Hulkkonen, M., Sogacheva, L., Manninen, H. E., Paasonen, P., Petäjä, T., Dal Maso, M., Aalto, P. P., Viljanen, A., Usoskin, I., Vainio, R., Mirme, S., Mirme, A., Minikin, A., Petzold, A., Hõrrak, U., Plaß-Dülmer, C., Birmili, W., and Kerminen, V.-M.: Atmospheric data over a solar cycle: no connection between galactic cosmic rays and new particle formation, Atmos. Chem. Phys., 10, 1885-1898, doi:10.5194/acp-10-1885-2010, 2010.

Kurtén, T., Noppel, M., Vehkamäki, H., Salonen, M., and Kulmala, M.: Quantum chemical studies of hydrate formation of $\mathrm{H}_{2} \mathrm{SO}_{4}$ and $\mathrm{HSO}_{4}^{-}$, Bor. Env. Res., 12, 431-453, $2007 \mathrm{a}$.

Kurtén, T., Torpo, L., Ding, C.-G., Vehkamäki, H., Sundberg, M. R., Laasonen, K., and Kulmala, M.: A density functional study 
on water-sulfuric acid-ammonia clusters and implications for atmospheric cluster formation, Geophys. Res., 112, D04210, doi:10.1029/2006JD007391, 2007b.

Kurtén, T., Torpo, L., Sundberg, M. R., Kerminen, V.-M., Vehkamäki, H., and Kulmala, M.: Estimating the NH3:H2SO4 ratio of nucleating clusters in atmospheric conditions using quantum chemical methods, Atmos. Chem. Phys., 7, 2765-2773, doi:10.5194/acp-7-2765-2007, 2007c.

Kurtén, T., Loukonen, V., Vehkamäki, H., and Kulmala, M.: Amines are likely to enhance neutral and ion-induced sulfuric acid-water nucleation in the atmosphere more effectively than ammonia, Atmos. Chem. Phys., 8, 4095-4103, doi:10.5194/acp8-4095-2008, 2008.

Kurtén, T. and Vehkamäki, H.: Investigating Atmospheric Sulfuric Acid-Water-Ammonia Particle Formation Using Quantum Chemistry, Adv. Quant. Chem., 55, 407-427, 2008.

Larson, L. J., Largent, A., and Tao, F.-M.: Structure of the sulfuric acid-ammonia system and the effect of water molecules in the gas phase, J. Phys. Chem. A, 103, 6786-6792, 1999.

Manninen, H. E., Nieminen, T., Riipinen, I., Yli-Juuti, T., Gagné, S., Asmi, E., Aalto, P. P., Petäjä, T., Kerminen, V.-M., and Kulmala, M.: Charged and total particle formation and growth rates during EUCAARI 2007 campaign in Hyytiälä, Atmos. Chem. Phys., 9, 4077-4089, doi:10.5194/acp-9-4077-2009, 2009.

Merrick, J. P., Moran, D., and Radom, L.: An Evaluation of Harmonic Vibrational Frequency Scale Factors, J. Phys. Chem. A, 111, 11683-1170, 2007.

Miehlich, B., Savin, A., Stoll, H., and Preuss, H.: Results obtained with the correlation energy density functionals of becke and Lee, Yang and Parr, Chem. Phys. Lett., 157, 200-206, 1989.

Murphy, S. M., Sorooshian, A., Kroll, J. H., Ng, N. L., Chhabra, P., Tong, C., Surratt, J. D., Knipping, E., Flagan, R. C., and Seinfeld, J. H.: Secondary aerosol formation from atmospheric reactions of aliphatic amines, Atmos. Chem. Phys., 7, 2313-2337, doi:10.5194/acp-7-2313-2007, 2007.

Müller, C., Iinuma, Y., Karstensen, J., van Pinxteren, D., Lehmann, S., Gnauk, T., and Herrmann, H.: Seasonal variation of aliphatic amines in marine sub-micrometer particles at the Cape Verde islands, Atmos. Chem. Phys., 9, 9587-9597, doi:10.5194/acp-99587-2009, 2009.

Mäkelä, J. M., Yli-Koivisto, S., Hiltunen, V., Seidl, W., Swietlicki, E., Teinilä, K., Sillanpää, M., Koponen, I. K., Paatero, J., Rosman, K., and Hämeri, K.: Chemical composition of aerosol during particle formation events in boreal forest, Tellus B, 53, 380-393, 2001.

Møller, C. and Plesset, M. S.: Note on an approximation treatment for many-electron systems, Phys. Rev., 46, 618-622, 1934.

Nadykto, A. B. and Yu, F.: Strong hydrogen bonding between atmospheric nucleation precursors and common organics, Chem. Phys. Lett., 435, 14-18, 2007.

Napari, I., Noppel, M., Vehkamaäki, H., and Kulmala, M.: An improved model for ternary nucleation of sulfuric acid-ammoniawater, J. Chem. Phys., 116, 4221-4227, 2002.

Noppel, M., Vehkamäki, H., and Kulmala, M.: An improved model for hydrate formation in sulfuric acid-water nucleation, J. Chem. Phys., 116, 218-228, 2002.

Ortega, I. K., Kurtén, T., Vehkamäki, H., and Kulmala, M.: The role of ammonia in sulfuric acid ion induced nucleation, Atmos. Chem. Phys., 8, 2859-2867, doi:10.5194/acp-8-2859-2008,
2008.

Re, S., Osamura, Y., and Morokuma, K.: Coexistence of neutral and ion-pair clusters of hydrated sulfuric acid $\mathrm{H}_{2} \mathrm{SO}_{4}\left(\mathrm{H}_{2} \mathrm{O}\right)_{\mathrm{n}}(\mathrm{n}=1-$ 5) - a molecular orbital study, J. Phys. Chem. A, 103, 35353547, 1999.

Riipinen, I., Sihto, S.-L., Kulmala, M., Arnold, F., Dal Maso, M., Birmili, W., Saarnio, K., Teinilä, K., Kerminen, V.-M., Laaksonen, A., and Lehtinen, K. E. J.: Connections between atmospheric sulphuric acid and new particle formation during QUEST IIIIV campaigns in Heidelberg and Hyytil, Atmos. Chem. Phys., 7, 1899-1914, doi:10.5194/acp-7-1899-2007, 2007.

Scott, A. P. and Radom, L.: Harmonic vibrational frequencies: an evaluation of Hartree-Fock, Møller-Plesset, quadratic configuration interaction, density functional theory, and semiempirical scale factors, J. Phys. Chem., 100, 16502-16513, 1996.

Seinfeld, J. H. and Pandis, S. N.: Atmospheric Chemistry and Physics: from Air Pollution to Climate Change, John Wiley \& Sons, New York, USA, 764-765, 1998.

Sellegri, K., Hanke, M., Umann, B., Arnold, F., and Kulmala, M.: Measurements of organic gases during aerosol formation events in the boreal forest atmosphere during QUEST, Atmos. Chem. Phys., 5, 373-384, doi:10.5194/acp-5-373-2005, 2005.

Sihto, S.-L., Kulmala, M., Kerminen, V.-M., Dal Maso, M., Petäjä, T., Riipinen, I., Korhonen, H., Arnold, F., Janson, R., Boy, M., Laaksonen, A., and Lehtinen, K. E. J.: Atmospheric sulphuric acid and aerosol formation: implications from atmospheric measurements for nucleation and early growth mechanisms, Atmos. Chem. Phys., 6, 4079-4091, doi:10.5194/acp-6-4079-2006, 2006.

Smith, J. N., Dunn, M. J., VanReken, T. M., Iida, K., Stolzenburg, M. R., McMurry, P. H., and Huey, L. G.: Chemical composition of atmospheric nanoparticles formed from nucleation in Tecamac, Mexico: Evidence for an important role for organic species in nanoparticle growth, Geophys. Res. Lett., 35, L04808, doi:10.1029/2007GL032523, 2008.

Smith, J. N., Barsanti, K. C., Friedli, H. R., Ehn, M., Kulmala, M. Collins, D. R., Scheckman, J. H., Williams, B. J., and McMurry, P. H.: Observations of aminium salts in atmospheric nanoparticles and possible climatic implications, Proceedings of the National Academy of Sciences of the United States of America, 107, 6632-6639, doi:10.1073/pnas.0912127107, 2010.

Smith, W., Yong, C. W., and Rodger, P. M.: DL_POLY: Application to molecular simulation, Molec. Simulat., 28, 385-471, 2002.

Soler, J. M., Artacho, E., Gale, J. D., Garcia, A., Junquera, J., Ordejon, P., and Sanchez-Portal, D.: The SIESTA method for ab initio order-N materials simulation, J. Phys.-Condens. Mat., 14, 2745-2779, 2002.

Spracklen, D. V., Carslaw, K. S., Kulmala, M., Kerminen, V.-M., Mann, G. W., and Sihto, S.-L.: The contribution of boundary layer nucleation events to total particle concentrations on regional and global scales, Atmos. Chem. Phys., 6, 5631-5648, doi:10.5194/acp-6-5631-2006, 2006.

Torpo, L., Kurtén, T., Vehkamäki, H., Sundberg, M. R., Laasonen, K., and Kulmala, M.: The significant role of ammonia in atmospheric nanoclusters, J. Phys. Chem. A, 111, 10671-10674, 2007.

Wang, L., Khalizov, A. F., Zheng, J., Xu, W., Ma, Y., Lal, V., and Zhang, R.: Atmospheric nanoparticles formed from heterogeneous reactions of organics, Nature Geosci., 3, 238-242, 
doi:10.1038/NGEO778, 2010.

Weber, R. J., Marti, J. J., McMurry, P. H., Eisele, F. L., Tanner, D. J., and Jefferson, A.: Measured atmospheric new particle formation rates: Implications for nucleation mechanisms, Chem. Eng. Commun., 151, 53-64, 1996.

Weber, R. J., Marti, J. J., McMurry, P. H., Eisele, F. L., Tanner, D. J., Jefferson, A.: Measurements of new particle formation and ultrafine particle growth rates at a clean continental site, J. Geophys. Res., 102, 4375-4385, 1997.
Yu, F.: Effect of ammonia on new particle formation: a kinetic $\mathrm{H}_{2} \mathrm{SO}_{4}-\mathrm{H}_{2} \mathrm{O}-\mathrm{NH}_{3}$ nucleation model constrained by laboratory measurements, J. Geophys. Res., 111, D01204, doi:10.1029/2005JD005968, 2006.

Yu, F. and Turco, R. P.: Ultrafine aerosol formation via ion-induced nucleation, Geophys. Res. Lett., 27, 883-886, 2000.

Yu, F. and Turco, R.: Case studies of particle formation events observed in boreal forests: implications for nucleation mechanisms, Atmos. Chem. Phys., 8, 6085-6102, doi:10.5194/acp-86085-2008, 2008. 